IZA DP No. 7594

The Perverse Effects of Job-Security Provisions on Job Security in Italy:

Results from a Regression Discontinuity Design

Alexander Hijzen

Leopoldo Mondauto

Stefano Scarpetta

August 2013 


\title{
The Perverse Effects of Job-Security Provisions on Job Security in Italy: Results from a Regression Discontinuity Design
}

\author{
Alexander Hijzen \\ $O E C D$ and IZA \\ Leopoldo Mondauto \\ Italia Lavoro and IMT Lucca \\ Stefano Scarpetta \\ $O E C D$ and IZA
}

Discussion Paper No. 7594

August 2013

IZA
P.O. Box 7240
53072 Bonn
Germany

Phone: +49-228-3894-0

Fax: +49-228-3894-180

E-mail: iza@iza.org

Any opinions expressed here are those of the author(s) and not those of IZA. Research published in this series may include views on policy, but the institute itself takes no institutional policy positions. The IZA research network is committed to the IZA Guiding Principles of Research Integrity.

The Institute for the Study of Labor (IZA) in Bonn is a local and virtual international research center and a place of communication between science, politics and business. IZA is an independent nonprofit organization supported by Deutsche Post Foundation. The center is associated with the University of Bonn and offers a stimulating research environment through its international network, workshops and conferences, data service, project support, research visits and doctoral program. IZA engages in (i) original and internationally competitive research in all fields of labor economics, (ii) development of policy concepts, and (iii) dissemination of research results and concepts to the interested public.

IZA Discussion Papers often represent preliminary work and are circulated to encourage discussion. Citation of such a paper should account for its provisional character. A revised version may be available directly from the author. 


\section{ABSTRACT}

\section{The Perverse Effects of Job-Security Provisions on Job Security in Italy: Results from a Regression Discontinuity Design *}

This paper analyses the impact of employment protection (EP) on the composition of the workforce and worker turnover using a unique firm-level dataset for Italy. The impact of employment protection is analyzed by means of a regression discontinuity design (RDD) that exploits the variation in EP provisions across firms below and above a size threshold. Using our RDD approach, we show that EP increases worker reallocation, suggesting that EP tends to reduce rather to increase worker security on average. We further show that this can be entirely explained by the fact that firms facing more stringent EP make a greater use of workers on temporary contracts. Our preferred estimates suggest that the discontinuity in EP increases the incidence of temporary work by 2-2.5 percentage points around the threshold. Moreover, further analysis suggests that the effect of employment protection persists among larger firms well beyond the threshold and may account for about $20 \%$ of the overall incidence of temporary work. There is also evidence that EP reduces labour productivity and this effect is to an important extent due to the impact of EP on worker reallocation and the incidence of temporary work.

JEL Classification: J42, J63, J65

Keywords: employment protection legislation, worker reallocation, temporary contracts, labour market duality

Corresponding author:

Stefano Scarpetta

OECD

Directorate for Employment, Labour and Social Affairs

2, Rue André Pascal

75775 Paris Cedex 16

France

E-mail: stefano.scarpetta@oecd.org

\footnotetext{
* This paper is based on a unique employer-employee dataset that was constructed in the context of OECD project "Analysing the role of policies for labor market resilience using micro data" by OECD and Italia Lavoro in collaboration with the Italian Ministry of Labour, the Italian Institute of Statistics (ISTAT) and the Italian Social Security Administration (INPS). We are grateful to the following people for making this project possible: Antonietta Mundo and Stefania Fioravanti (INPS), Enrico Giovannini, Manlio Calzaroni, Giuliana Coccia, Giuseppe Garofalo and Monica Consalvi (ISTAT), Grazia Strano (Italian Ministry of Labour), Paolo Reboani, Maurizio Sorcioni, Marco Manieri and Simona Calabrese (Italia Lavoro), Massimo Callori and Claudia Poddighe (Crisma). We are grateful for useful comments and suggestions from Andrea Bassanini, Ryoichi Imai, Marco Leonardi, Michele Pellizzari, Stepan Jurajda, Marcello Sartarelli, Fabiano Schivardi, Paolo Sestito, Jan Svejnar as well as seminar participants at Italia Lavoro (Italian Ministry of Labour and Social Affairs), the OECD, the University of Milan, the University of Tuebingen and participants of a Conference on Job and Worker Flows in Kyoto, the third SEEK conference in Mannheim, the ASSA Meeting in San Diego and the IZA-World Bank annual conference on "Employment and Development". The views expressed in this paper are those of the authors and do not necessarily reflect those of Italia Lavoro, the OECD or its member states. All remaining errors are our own.
} 


\section{Introduction}

Over the past two decades, the effects of employment protection (EP) legislation on labour market outcomes have attracted a lot of attention with a rapidly growing number of theoretical and empirical studies and often tense policy debates. EP is generally justified by the need to protect workers from unfair behaviour on the part of their employers, the fact that imperfections in financial markets limit workers' ability to insure themselves against the risk of dismissal and by the need to preserve firm-specific human capital by preventing the destruction of jobs that are viable in the longer-term (e.g. Pissarides, 2010). But by imposing implicit or explicit costs on the firm's ability to accommodate its workforce to the evolution of demand and technological changes, EP may hinder efficient workforce adjustment, by not only reducing job destruction but also discouraging job creation (e.g. Mortensen and Pissarides, 1994) with a potential adverse effect on labour reallocation and economic efficiency (for a review of the empirical evidence, see e.g. Skedinger, 2011; Martin and Scarpetta, 2012).

Despite significant attention, the jury is still out on the effects of EP on labour market outcomes and economic efficiency. One of the problems is that much of the evidence is based on cross-country time series data on the impact of EP on employment and unemployment rates (e.g. Bassanini and Duval, 2006; Blanchard and Wolfers, 2000; Baker et al. 2005, Fiori et al. 2012). While such studies have played an important role in the policy debate on employment protection, this evidence remains plagued by omitted variable and measurement problems. To overcome these problems, a recent literature has exploited withincountry variation, over time, across sectors or types of firms using difference-in-difference techniques. One strand of this literature has exploited within-country variations in the expected impact of EP across sectors characterised by differences in the propensity to adjust the workforce techniques (Micco and Pages, 2007; Haltiwanger et al. 2006 and 2010; Bassanini et al., 2009; Cingano et al., 2010). Another strand has exploited differences in regulatory treatment across regions (Autor et al., 2007 for the US), workers of different age (Kugler et al., 2003, for Spain) or firms of different size (Boeri and Jimeno, 2005; Kugler and Pica, 2008; Schivardi and Torrini, 2008, for Italy; Centeno and Novo, 2012, for Portugal; Venn, 2010, for Turkey; and Gal et al., 2012, for 10 OECD countries).

The present paper follows this latter line of investigation by analyzing the role of firm-size exemptions with respect to of EP it Italy using a unique nationally-representative firm-level dataset for the period 2008-2009. The impact of employment protection is analyzed by means of a regression discontinuity design (RDD) that exploits the variation in EP provisions between small and large firms. In particular, the Italian legislation on EP - until a recent reform -- imposed significantly higher costs in case of an unfair dismissal of an individual worker with a permanent contract to firms above a threshold of 15 employees compared with those below this threshold. We demonstrate that the use of a RDD is 
appropriate in the present context by showing that the firm-size density is continuous around the threshold, firms just below the threshold do not display an unusually low propensity to grow, and the available control variables are balanced around the threshold. The RDD is used to analyse the impact of employment protection on worker reallocation, the incidence of temporary work and labour productivity in Italy.

Much of the previous literature for Italy has focused on the impact of firm-size exemptions with respect to employment protection on the incidence and growth of small firms. This literature concludes that the role of employment protection is, at best, limited (Garibaldi et al. 2004; Schivardi and Torrini, 2008). Schivardi and Torrini (2008) posit that firms circumvent employment protection by substituting permanent for temporary workers and present some indirect evidence to support their conjecture. In particular, they show that worker turnover is higher among large firms just above the threshold than in small firms, which is at odds with the intended purpose of employment protection of increasing job security. The empirical evidence on the role of employment protection on the incidence of temporary work to date is relatively limited. Kahn (2010) uses country-level variation in employment protection across nine European countries and over the period 1996-2001. A recent study for Portugal (Centeno and Novo, 2012) exploits the reduction in the threshold for the regulation of open-ended contracts to analyse the effects of employment protection on worker reallocation and the incidence of temporary work.

Using our RDD approach, we show that EP tends to increase worker reallocation, suggesting that EP may reduce rather to increase worker security. We further show that this can be entirely explained by the impact of EP on the use of workers on temporary contracts. Our preferred estimates suggest that the discontinuity in EP on the incidence of temporary work is economically large, increasing the incidence of temporary work by 2-2.5 percentage points for the firms around the threshold. Moreover, our analysis also suggests that the effect of employment protection is likely to persist among larger firms well beyond the threshold and may account for about $20 \%$ of the overall incidence of temporary work. There is also evidence that EP reduces labour productivity and that this effect is to an important extent related to its impact on the incidence of temporary work and worker reallocation.

These results are important in the context of the recent reforms of employment protection in Italy (2012) as well as in a number of other European countries to reduce the often large divide in the protection between workers employed on open-ended contracts and those on temporary and other atypical contracts. Indeed, the present results suggest that the asymmetric liberalisation of temporary and other atypical contracts while leaving in place stringent regulations for permanent contracts - as observed in many, mainly European countries as well as Korea and Japan, over the past two decades (see e.g. Venn, 2009) has encouraged firms to substitute temporary for regular workers. While the long-run effects of this 
asymmetric liberalisation on overall employment may be small, (see e.g. Boeri and Garibaldi, 2007; Bentolila et al., 2008), this shift from regular to temporary employment may have a number of side effects. In particular, it may distort the optimal composition of employment and reduce workers' involvement in training and their commitment to work. This, in turn, could have a negative impact on dynamic efficiency, contribute to greater dualism in the labour market between those who are able to maintain a regular contract (often the insiders) and those employed on temporary contracts (often youths and other workers with limited skills or work experience) and increase the social costs of adjustment by shifting the burden to outsiders (Saint Paul, 1996). This latter phenomenon has been very marked in the recent great recession, when a number of European countries and Japan, characterized by large shares of temporary workers in total employment, have seen job losses largely concentrated among these workers (OECD, 2010 and 2012).

The remainder of this paper is organised as follows. Section 2 provides an overview of the EP in Italy with respect to permanent and temporary contracts in place during the period of interest for our study and after the recent reforms that took place in 2012. Section 3 discusses the various data sources used in this study, details the exact way the firm-size threshold is measured, as this is crucial for our identification strategy, and provides basic descriptive statistics on our data. Section 4 presents the regression discontinuity design and shows empirical evidence that suggests that this is an appropriate identification strategy in the present context. It also discusses how the regression discontinuity design can be complemented with a difference-in-difference estimation strategy. Section 5 present our econometric results and discusses their robustness using a wide variety of different specifications and robustness tests. Based on the micro-econometric estimates, Section 6 sheds some light on the aggregate implications of employment protection on the incidence of temporary work. Section 7 concludes.

\section{Institutional background}

This section provides a detailed account of the regulation of permanent and temporary contracts up to 2012 as a brief discussion of the reforms that were implemented in 2012. The econometric analysis in this paper focuses on the period 2008-2009 before the recent reforms.

\subsection{The legislation for permanent contracts until 2012}

Employment protection, including dismissal procedures, was first regulated in Italy in 1966 (Law No. 604). The law established that employers could dismiss workers with a permanent (open-ended) contract either for economic reasons (considered as fair "objective" motives, giustificato motivo oggettivo) or in case of misconduct (considered as fair "subjective" motives, giusta causa or giustificato motivo 
soggettivo). However, a worker could take employers to court and have a judge determine if the dismissal was fair or unfair. If the dismissal was judged unfair, employers had the choice to either reinstate the worker or pay severance, which depended on tenure and firm size (more or less than 60 employees). ${ }^{1}$ In the case of fair dismissals, including those for economic reasons, workers were not entitled to any form of compensation.

In 1970, the Statuto dei Lavoratori (Law No. 300) introduced significant changes in dismissal procedures. In particular, the Article 18 of the Statuto effectively lowered the firm-size threshold that determines the entitlement of workers in the case of unfair dismissal from 60 to 15 employees and established the so-called "tutela reale" for firms with more than 15 employees. In the case of unfair dismissal, the employer either has to reinstate the worker and pay for the foregone wages during the period between the dismissal and the sentence or instead may be required to make a severance payment worth 15 monthly salaries and to compensate the worker for the wages lost during the trial period. Importantly, in contrast to the situation before 1970, the choice between reinstatement and severance payments was shifted entirely to the employee. ${ }^{2}$ For firms with 15 employees or less the changes imposed by Article 18 did not apply: the choice between reinstatement and severance pay in the case of unfair dismissals remained with the employer and mandated severance pay was much lower. As before the change in the law, workers dismissed for fair reasons were not entitled to any form of compensation. ${ }^{3}$

In 1990, the employment protection regime for firms with 15 or fewer employees was reformed through the introduction of the so-called "tutela obbligatoria" (Law No. 108), which is similar in spirit to the previous regime for small firms, but increased the cost of unfair dismissals. As before, the employer decides whether a worker is reinstated or a severance payment is provided in the case of an unfair dismissal. Severance pay ranges from a minimum of 2.5 to a maximum of 14 months of the last salary pay for workers with high seniority. Note that in the case of reinstatement, the worker is not eligible to compensation for wages lost during the period between the dismissal and the court's ruling.

As a result of the threshold of 15 employees, the cost of unfair dismissal differs substantially above and below the threshold. In particular, for firms above the threshold the costs of an unfair dismissal are significantly higher than those of a firm below the threshold: i) they are generally forced to reinstate the

$1 \quad$ Severance pay for unfair dismissal ranged between 5 and 12 months of the last salary, depending on the size of the firm, the tenure of the worker and the behaviour of the parties during the dispute. The maximum severance pay was reduced to 8 months in case of a worker with tenure of less than 30 months and extended to 14 months for a worker with tenure greater than 20 years. Firms with less than 60 employees had to pay half of the severance paid by firms with more than 60 employees.

2 In practice, this usually meant that workers had to be reinstated in the case of unfair dismissal.

Discriminatory dismissals, such as for ethnic, religious or trade-union membership reasons are never allowed; in this case a worker always has the right to be reinstated in the job irrespective of firm's size. 
dismissed workers and compensate them for foregone wages during the often lengthy trial period; ${ }^{4}$ ii) they are also called to pay a high penalty for the omitted social contributions to the Social Security Administration (INPS), which is proportional to the trial's duration; and iii) if the worker opts for severance pay, this is up to six times higher than in small firms.

A key factor that increases de facto firing costs of dismissals for economic reasons for firms above the threshold is the absence of a stringent definition of fair dismissal and the limited flexibility on the part of judges to adjust the sanction to the severity of the fault. Unfair dismissals generally result in reinstatement whereas in the case of fair dismissals workers do not receive any form of compensation even though they may not be at fault (e.g. dismissal for economic reasons). The absence of a stringent definition of fair dismissal leaves room for various interpretations and in this sense the judge's discretion assumes a major role. In practice, the absence of compensation for workers in the case of fair dismissals has induced many judges to adopt a broad interpretation of unfair dismissal, increasing considerably the expected cost of dismissals for economic reasons, particularly in the context of depressed labour markets. Indeed, Ichino et al. (2003) show that local labour market conditions influence the court's decisions. Judges in regions with high unemployment rates are more likely to rule in favour of the workers than judges in regions with low unemployment rates, introducing de facto a higher firing cost for firms operating in economically-depressed areas. The high expected cost of firing for economic reasons and the uncertainty of trials' outcomes discourage large firms from initiating dismissal procedures (Ichino, 1996).

It should be noted that other relevant regulations apply to firms above a certain size threshold, even if these thresholds are defined using somewhat different rules than those applying to the Article 18 discussed above. The threshold of 15 employees is also relevant for the establishment of the so-called "Rappresentanze Sindacali Aziendali" (RSA) a firm-level worker organisation with the right to call for general meetings, establish referendums, and post union-related posters within the establishment. Firms with more than 15 employees also have the right to a worker representative for safety-related issues. And since 1991, collective dismissals procedures are in place above the 15 employee threshold: for the dismissal of 5 or more workers, the legislation requires proof of the credible risk of bankruptcy ${ }^{5}$ and implies additional and often lengthy negotiations with the representative unions even if it does not generate further direct firing costs. Finally, firms employing more than 10 workers are obliged to hire disadvantaged workers, which refer to registered long-term unemployed, and since 1999 firms employing more than 15 workers must employ a quota of workers with disabilities. These additional constraints applying to firms

\footnotetext{
$4 \quad$ The average time required for the court ruling in Italy is very long, 23 months. Moreover, almost $60 \%$ of the labour cases are appealed, one of the highest in the OECD countries. See Venn, 2009, for further details.

$5 \quad$ Firms undergoing temporary crisis or in need of restructuring may access supplementation schemes (Cassa Integrazione Guadagni) instead of firing (part of) their workforce; see below for further details.
} 
above the 15 employee threshold could potentially add some noise in our estimates. However, the empirical evidence on the impact of these other constraints on firms' behaviour does not lend support to the idea that they play a large role. ${ }^{6}$ Nevertheless, the main motivation for complementing the RDD with a difference-in-differences approach is to control for the role any rules or regulations other than employment protection that make use of a similar firm-size threshold.

\subsection{The legislation for temporary contracts until 2012}

Art.1 of Law No.230 of 1962 established that the relationship between the employee and the employer should be on a permanent basis in principle and limited the use of temporary contracts to exceptional circumstances. However, the presence of high dismissal costs of permanent workers, the need for an adequate flexibility for firms to adjust labour inputs according to production needs and the desire to curtail the development of informal working arrangements have motivated a series of reforms with respect to the regulation of temporary and other atypical labour contracts from the mid-1980s onwards.

Following the prolonged economic crisis in the early 1980s, the government started a reform process which eventually resulted in the adoption of Art.23 of Law No. 28 in 1987, which stipulated that employers could hire, in agreement with labour unions, a certain fraction of their workers on a temporary contract. Regarding the firing cost of a temporary worker, the legislation allows the dismissal only on a just cause basis (giusta causa or giustificato motivo soggettivo). Employers cannot fire a temporary worker for objective motives (giustificato motivo oggettivo). In the case of unfair dismissal, the worker has the right to receive a payment equal to the foregone wages between the firing date and the expected expiration of his temporary contract. Differently from permanent workers, the firing cost for unfair dismissal of temporary employees is the same for firms of all sizes.

Furthermore, the Treu reform in 1997 and the Biagi Law in 2003 promoted further flexibility in the Italian labour market, by liberalizing the use of temporary contracts. Both dealt with the regulation of temporary work agencies (TWAs), while the latter law also introduced new contractual forms of temporary nature (i.e. staff leasing, job on call, job sharing). Particularly, the Biagi Law replaced the existing consultant agreements (the so-called "contratti di collaborazione coordinata e contitnuativa") with project labour agreements (the so-called "contratti a progetto"). These are temporary contracts that can be considered as 'semi-dependent' since they are midway between those of dependent employment and self-

\footnotetext{
6 In particular, Schivardi and Torrini (2008) using a survey of Metalworking Firm Organisation, show that the share of firms with an RSA and the share of firms with a firm-level contract, whilst generally increasing with firm size, do not show any kink at the 15 threshold. All in all, it seems fair to say that the discontinuity on RSA establishment should not affect in a sensible way the interpretation of our results.
} 
employment. Although the two reforms introduced many novel elements to the regulation of the Italian labour market, they did not affect the employment protection level of permanent contracts.

In conclusion, the Italian labour market is characterized by a strong discontinuity in the employment protection of permanent contracts around the threshold of 15 employees, with significantly higher dismissal costs and greater uncertainty in the legal procedures for enterprises above this threshold. Conversely, the regulation for hires and separations of temporary contracts, in their various forms (i.e. dependent or semi-independent), is uniform for firms with less or more than 15 employees. Moreover, the strong protection for workers on permanent contracts in large firms and the increased scope for employing workers on temporary contracts during the past 25 years may have provided incentives to employers to substitute permanent for temporary workers.

\subsection{The 2012 Labour Reform}

A comprehensive labour market reform was introduced in Italy in June 2012. The reform covers rules for hiring, separation as well as apprenticeships and unemployment benefits.

Concerning the regulation of non-standard contracts, the reform introduced a series of norms aimed at combating abuses in the use of certain forms of atypical contracts and reducing the incentives to hiring workers on non-permanent contracts. In particular, the cooling-off period between two fixed-term contracts has been extended; social security contributions for fixed-term contracts were increased and more strict tests introduced to justify the use of independent contractors.

In addition, the 2012 reform introduced changes in the procedures for the dismissal of a worker with an open-ended contract and modified the sanctions imposed on employers subject to Article 18, i.e. those with more than 15 employees, in case of unfair dismissal. More specifically, the reform made two major changes: i) the judge (and not the worker) decides whether reinstatement should be envisaged once a dismissal is ruled unfair; and ii) the judge is now allowed to graduate the sanction depending on the severity of the fault in the dismissal, whereas before the reform the judge did not have any discretion once it was assessed that the dismissal was unfair and the employee had opted for reinstatement. Under the new legislation, reinstatement can be ordered by the judge in the case of most severe violation of the law (e.g. in case of discriminatory reasons behind the dismissal) as in a number of other OECD countries. The second level of sanction also includes the reinstatement but limits the pay for foregone wages to a maximum of 12 months. The third and fourth levels relate to dismissals for economic reasons. They only allow for severance pay and not reinstatement. Third level sanctions provide for severance compensation ranging from 12 to 24 months of pay depending on the worker' tenure, firm size, and the behaviour of the 
parties during the trial, while for fourth level sanctions allow for compensation ranging from 6 to 12 months. Under the new regime, thus, the judge has the possibility of graduating the sanction, with the reinstatement envisaged only when the dismissal was manifestly groundless. ${ }^{7}$

All in all, these changes have the potential to reduce significantly the de facto dismissal costs for firms above 15 employees, by reducing the uncertainty and time involved in a dismissal procedure and the expected cost in case of unfair dismissals. However, the judges have a higher degree of discretion and much will depend on the jurisprudence that will develop over time. In any event, these elements of the reform are likely to imply that the discontinuity at 15 has been significantly reduced.

\section{Data description}

This section provides a detailed description of the various data sources used in our analysis. The core of the dataset used for this paper is based on the collection of three different administrative data sources. The different archives are linked through the use of unique firm tax codes. The resulting dataset is nationally representative of all Italian private firms with at least one employee in 2006. A key feature of the dataset is that it provides information on all hires, separations and contract conversions and allows tracking worker transitions between firms in our sample. Information about firms' utilization of the Italian short-time working (STW) schemes (Cassa Integrazione) is also available. Figure 1 presents the key sources of our dataset.

\footnotetext{
${ }^{7}$ In addition, the reform also requires employers to specify the motivation of dismissal when notifying it to the worker (previously, this was required only after seven days and if requested by a worker in the first 15 days since notification); simplifies the procedures for dispute resolution, through the introduction of a seven days mandatory conciliation process between the parties to assess whether a mutual agreement could be reached; and stipulates that all labour disputes be treated via a fast-track judicial procedure.
} 
Figure 1. Data sources

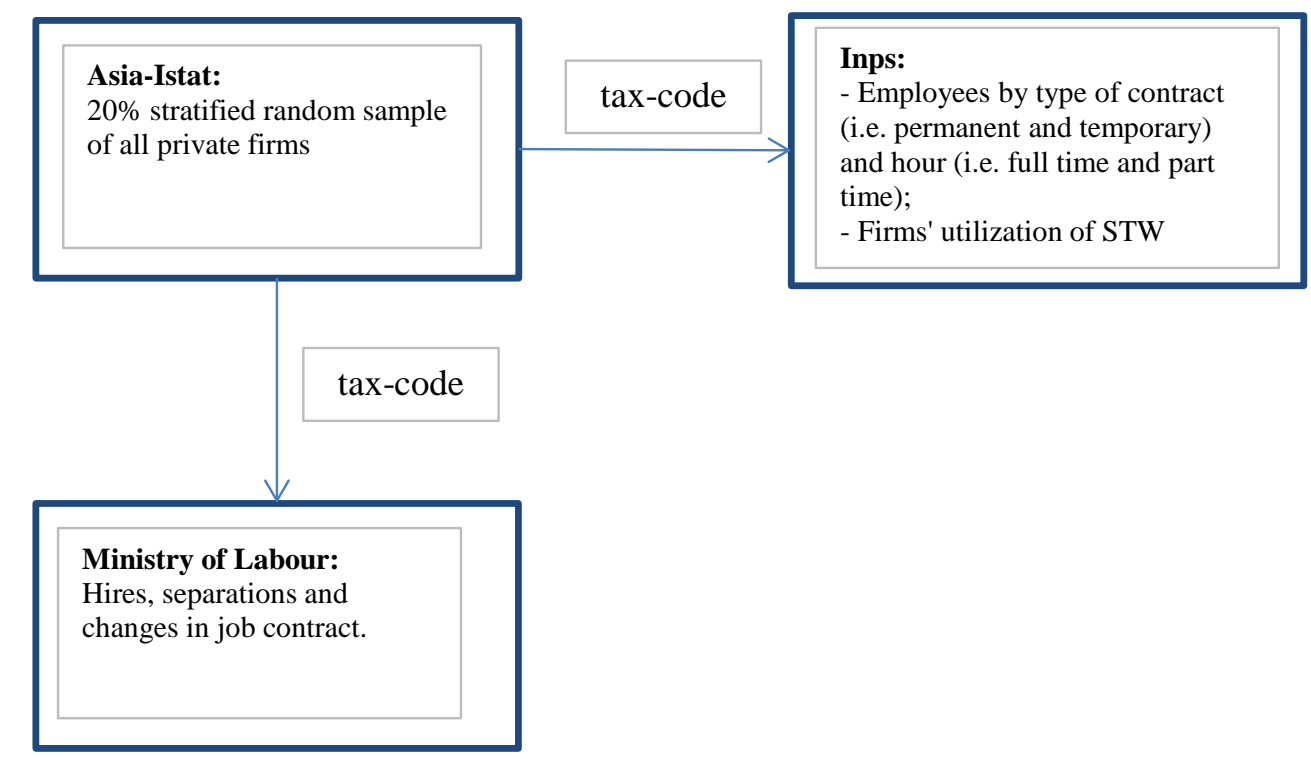

\subsection{Data sources}

The first dataset consists of the Italian Statistical Register of Active Enterprises (ASIA), which is the most reliable source on the universe of the Italian firms. It includes firm-level data obtained by the integration of administrative sources, coming from public agencies and private companies, and statistical sources managed by the National Institute of Statistics (hereafter, ISTAT). ${ }^{8}$ ASIA provides annual information on sales, employment and allows distinguishing between employees and independent-contract workers. See Consalvi et al. (2008) for more details.

The firm-level dataset used in this paper represents a $20 \%$ stratified random sample of all private firms active in 2006 with at least one employee. ${ }^{9}$ These firms are followed during the period 2001-2009. The public sector and agriculture are excluded from the analysis. A stratified sample is used to ensure its representativeness in terms of firm size, economic activity (2 digits) and region. ${ }^{10}$

The second source comes from the Italian Social Security Administration (INPS), from which we obtain quarterly data on the level of employment for permanent and temporary employees as well as fulltime and part-time workers. This information is available for the period 2008Q1-2011Q1. Furthermore, it

8 Information in this dataset is drawn from the Italian Social Security Administration, the Italian National Revenue Service (i.e. Agenzia delle Entrate) and the demographic information comes from the Chamber of Commerce.

9 The sample size decreases by $15 \%$ between 2006 and 2009 due to attrition. As firm exit is higher among small firms and no new small firms enter our sample, the 2009 sample slightly underrepresents small firms.

$10 \quad$ While the random nature of our sample ensures that the data are representative at the country level, this is not necessarily the case for sub-samples due to sampling variability. 
provides information on firms' utilization of the Italian short-time working scheme, the Cassa Integrazione Guadagni (in terms of the number of hours subsidized and the number of beneficiaries).

Data on changes in the firm's workforce are collected from the New Informative System of Compulsory Communications (CC), managed by the Italian Ministry of Labour. The Ministerial Decree of October 30, 2007 obliges Italian firms to notify electronically all hires and separations, extensions or conversions of job contracts to the Ministry of Labour. Until then, the notifications were transmitted on a paper basis. After a transitory phase during which firms could send notifications by mail, electronic notification became compulsory from March 2008. From this date, the Informative System records each workforce movement in private and public Italian firms. Moreover, for each worker movement, it provides information on the precise date of the event, the identity of the worker, the identity of the firm and a rich set of worker characteristics: i.e. age, gender, nationality, educational level, domicile and for foreigners the reason and the term of residence permission, as well as job characteristics (the type of contract, parttime/full-time, standard weekly hours). ${ }^{11}$

Our final dataset consists of 122,326 firms with complete information in 2008 and 2009 and at least one permanent employee.

\subsection{Measuring the threshold}

Since our paper uses the discontinuity of employment protection by firm size to identify its impact, the accurate measurement of firm size is crucial. In the Labour Code, firm size is defined in terms of the number of full-time equivalent dependent employees. This means that all temporary and permanent employees need to be included in the computation of employment, while independent contractors and apprentices are not concerned. It also implies that all permanent and temporary employees should be counted by taking into account their usual working hours. ${ }^{12}$

In order to calculate the number of employees for the EP threshold, we combine the ISTAT and INPS archives. The ISTAT data are used to measure the average number of employees within each firm, while the INPS data are used to obtain the shares of permanent and temporary employees and those of full-time and part-time workers. Since in the case of part-time workers, details about the number of usual hours worked are not available, we assume that they work half time $(50 \%)$. We do not have any information in

11 Unfortunately, we do have this type of information for the stock of workers but only for those who are hired, separated or whose contract is converted. This precludes conducting the present analysis at the worker level or analysing the role of worker characteristics.

12 The second column of Table A.1 in the annex summarises how employment should be computed across different contract types and working time according to the law and how it is measured in the present and previous studies. 
our data to determine whether employees are apprentices or not. However, considering the relatively low incidence of apprenticeships in Italy, the resulting bias in our computation of the threshold is likely to be negligible. ${ }^{13}$

To shed some light on the importance of these measurement issues for the classification of firms above and below threshold, Figure A2 of the Annex compares the differences in the classification of firms using our approach (M1) and that based on the total number of employees, without distinguishing partimers (M2). ${ }^{14}$ From the left to the right, the figure, respectively, gives the share of firms that are classified as above the threshold according to M2 and below the threshold using M1 for gradually declining bandwidth choices. The Figure suggests that problems of misclassification are relatively limited when using a large bandwidth (e.g. 3\% when using the largest bandwidth), while it increases rapidly the smaller the bandwidth (e.g. about $20 \%$ in the smallest bandwidth).

This simulation provides a strong argument for using relatively large bandwidths, particularly in cases where doubts over the accurate measurement of the threshold exist. ${ }^{15}$ Another reason for using relatively large bandwidths in the present context is the nature of our firm-size variable which is continuous with spikes at integer values. Moreover, cross-validation tests such as those suggested by Imbens and Lemieux (2008) based on the mean squared error provide little guidance to determining the optimal bandwidth in such a context. We, therefore, present results based on alterative bandwidth choices. As a general rule, more flexible specifications which allow for a relatively sophisticated relationship between the outcome variable of interest and firm size argue for using a relatively broad bandwidth, while non-parametric or linear specifications are more appropriate in the close vicinity of the threshold. In the sensitivity analysis, we further assess the sensitivity of our results to the use of alternative firm size measures that have been used in the literature.

\subsection{Descriptive statistics}

Since we focus our analysis on firms with 6 to 25 employees, it is interesting to explore the implications of this sample restriction for the size of the sample and its composition. It also provides a first indication of the relationship between the main outcome variables of interest and firm size, which may

\footnotetext{
13 As shown in Table A1 in the Annex, the availability of detailed information on the composition of the workforce in our employer-employee dataset allows for an arguably more precise definition of firm size than what was possible in previous studies.

14 This is the measure used in Schivardi and Torrini (2008).

15 This is also a reason for not using distance-weighted local linear estimation techniques in the econometric analysis of this paper.
} 
reflect the role of employment protection around the threshold, but also the independent effect of firm size. Table 1 represents descriptive statistics on the variables used in the analysis by firm size.

Restricting the analysis to firms with 6 to 25 employees means focusing on slightly less than one third (29\%) of all Italian firms with at least one permanent employee. Micro-firms with less than 6 employees account for $64 \%$ of the sample, while firms with more than 25 employees account for just $7 \%$. These data, thus, confirm the relative importance of micro and small firms in the Italian economy.

The focus on firms with 6 to 25 employees also has implications for the composition of our sample. In the last two columns of the table, we compare the average values of the main variables in our dataset across two different samples. The first compares small firms defined here as firms with 6-15 employees with larger firms defined as firms with 16-25 employees, while the second compares firms within our estimation sample (i.e. firms with 6-25 employees) with all other firms. A series of t-tests for differences in the means across different firm-size groups is also presented. These tests show that there are systematic differences in the characteristics of small and large firms, as well as between firms in our estimation sample and those that are excluded. Significant differences are also observable in the industry and geographical distribution.

Differences in the characteristics of small and large firms may be related to the differential role of employment-protection provisions above and below the 15 employee threshold, but also reflect the independent effect of firm size or the endogenous of response of firms to employment protection. The main challenge of the econometric analysis is to accurately control for the independent effect of firm size and address the possibility that firms self-select into size groups. 
Table 1. Summary statistics by firm size, 2009

\begin{tabular}{|c|c|c|c|c|c|c|c|}
\hline \multirow[t]{2}{*}{ Variable names } & \multicolumn{5}{|c|}{ Mean value (standard deviation) } & \multicolumn{2}{|c|}{ T-tests } \\
\hline & $\leq 5$ & $<5,15]$ & $<15,25]$ & $>25$ & All & $\begin{array}{c}\mathbf{H}_{0}: \\
\mathrm{E}[\mathbf{y}]_{<15,25]}=\mathrm{E}[\mathbf{y}]_{<5,15]}\end{array}$ & $\begin{array}{c}\mathrm{H}_{0}: \\
\mathrm{E}[\mathrm{y}]_{<5,25]}=\mathrm{E}[\mathrm{y}]_{\leq 5 \&>25}\end{array}$ \\
\hline total employment & $\begin{array}{r}2.33 \\
(1,18)\end{array}$ & $\begin{array}{r}8.66 \\
(2,75)\end{array}$ & $\begin{array}{l}19.14 \\
(2,86)\end{array}$ & $\begin{array}{r}129.06 \\
(420,32)\end{array}$ & $\begin{array}{r}13.18 \\
(113,52)\end{array}$ & $259.63 * * *$ & $-5.64 * * *$ \\
\hline number of permanent employees & $\begin{array}{r}2.22 \\
(1,12)\end{array}$ & $\begin{array}{r}8.00 \\
(2,73)\end{array}$ & $\begin{array}{l}17.40 \\
(3,56)\end{array}$ & $\begin{array}{r}116.34 \\
(346,98)\end{array}$ & $\begin{array}{r}12.01 \\
(94,40)\end{array}$ & $224.13 * * *$ & $-5.97 * * *$ \\
\hline number of temporary employees & $\begin{array}{r}0.11 \\
(0,31)\end{array}$ & $\begin{array}{r}0.65 \\
(1,03)\end{array}$ & $\begin{array}{r}1.74 \\
(2,39)\end{array}$ & $\begin{array}{r}12.72 \\
(206,97)\end{array}$ & $\begin{array}{r}1.17 \\
(53,80)\end{array}$ & $55.82 * * *$ & -1.43 \\
\hline number of independent employees & $\begin{array}{r}0.54 \\
(0,81)\end{array}$ & $\begin{array}{r}0.57 \\
(0,90)\end{array}$ & $\begin{array}{r}0.50 \\
(0,94)\end{array}$ & $\begin{array}{r}0.29 \\
(1,00)\end{array}$ & $\begin{array}{r}0.53 \\
(0,86)\end{array}$ & $-4.81 * * *$ & $8.02 * * *$ \\
\hline total excess worker reallocation rate & $\begin{array}{r}0.56 \\
(1,47)\end{array}$ & $\begin{array}{r}0.54 \\
(0,69)\end{array}$ & $\begin{array}{r}0.51 \\
(0,63)\end{array}$ & $\begin{array}{r}0.50 \\
(1,49)\end{array}$ & $\begin{array}{r}0.55 \\
(1,29)\end{array}$ & $-2.92 * * *$ & $-2.92 * * *$ \\
\hline share of temporary employees of dependent employees & $\begin{array}{r}0.04 \\
(0,09)\end{array}$ & $\begin{array}{r}0.08 \\
(0,11)\end{array}$ & $\begin{array}{r}0.09 \\
(0,12)\end{array}$ & $\begin{array}{r}0.09 \\
(0,12)\end{array}$ & $\begin{array}{r}0.05 \\
(0,10)\end{array}$ & $9.55 * * *$ & $55.32 * * *$ \\
\hline share of independent employees of total employment & $\begin{array}{r}0.15 \\
(0,21)\end{array}$ & $\begin{array}{r}0.06 \\
(0,09)\end{array}$ & $\begin{array}{r}0.02 \\
(0,04)\end{array}$ & $\begin{array}{r}0.01 \\
(0,02)\end{array}$ & $\begin{array}{r}0.11 \\
(0,18)\end{array}$ & $-28.31 * * *$ & $-75.08 * * *$ \\
\hline temporary excess worker reallocation rate & $\begin{array}{r}4.04 \\
(5,09)\end{array}$ & $\begin{array}{r}3.02 \\
(3,72)\end{array}$ & $\begin{array}{r}2.71 \\
(3,36)\end{array}$ & $\begin{array}{r}2.89 \\
(7,20)\end{array}$ & $\begin{array}{r}3.33 \\
(4,97)\end{array}$ & $-4.71 * * *$ & $-14.3 * * *$ \\
\hline permanent excess worker reallocation rate & $\begin{array}{r}0.13 \\
(0,44)\end{array}$ & $\begin{array}{r}0.10 \\
(0,24)\end{array}$ & $\begin{array}{r}0.08 \\
(0,17)\end{array}$ & $\begin{array}{r}0.07 \\
(0,20)\end{array}$ & $\begin{array}{r}0.12 \\
(0,38)\end{array}$ & $-6.67 * * *$ & $-11.33 * * *$ \\
\hline independent employee excess reallocation rate & $\begin{array}{r}0.02 \\
(0,25)\end{array}$ & $\begin{array}{r}0.08 \\
(0,59)\end{array}$ & $\begin{array}{r}0.24 \\
(1,36)\end{array}$ & $\begin{array}{r}0.43 \\
(2,42)\end{array}$ & $\begin{array}{r}0.06 \\
(0,59)\end{array}$ & $15.51 * * *$ & $-2.62 * * *$ \\
\hline $\log$ labour productivity & $\begin{array}{l}11.58 \\
(0,93)\end{array}$ & $\begin{array}{l}11.66 \\
(0,89)\end{array}$ & $\begin{array}{l}11.80 \\
(0,93)\end{array}$ & $\begin{array}{r}11.89 \\
(1,18)\end{array}$ & $\begin{array}{r}11.63 \\
(0,94)\end{array}$ & $10.57 * * *$ & $12.34 * * *$ \\
\hline share of STW beneficiaries of dependent employees & $\begin{array}{r}0.03 \\
(0,14)\end{array}$ & $\begin{array}{r}0.08 \\
(0,20)\end{array}$ & $\begin{array}{r}0.12 \\
(0,23)\end{array}$ & $\begin{array}{r}0.13 \\
(0,24)\end{array}$ & $\begin{array}{r}0.06 \\
(0,17)\end{array}$ & $13.6 * * *$ & $41.2 * * *$ \\
\hline age of the firm in years & $\begin{array}{r}17.93 \\
(11,06)\end{array}$ & $\begin{array}{r}19.04 \\
(12,05)\end{array}$ & $\begin{array}{r}20.86 \\
(12,93)\end{array}$ & $\begin{array}{r}24.56 \\
(15,37)\end{array}$ & $\begin{array}{r}18.78 \\
(11,86)\end{array}$ & $10.21 * * *$ & $10.31 * * *$ \\
\hline Industry & & & & & & & \\
\hline Construction & 0.18 & 0.18 & 0.14 & 0.08 & 0.17 & $-6.9 * * *$ & $2.83 * * *$ \\
\hline Electricity, gas and & 0.00 & 0.00 & 0.00 & 0.01 & 0.00 & $1.9 *$ & -0.08 \\
\hline Financial intermediat & 0.02 & 0.01 & 0.01 & 0.03 & 0.02 & -0.67 & $-13.81 * * *$ \\
\hline Hotels and restaurant & 0.07 & 0.05 & 0.03 & 0.02 & 0.06 & $-5.83 * * *$ & $-10.75 * * *$ \\
\hline Manufacturing & 0.21 & 0.36 & 0.47 & 0.51 & 0.28 & $15.1 * * *$ & $48.41 * * *$ \\
\hline Mining and quarrying & 0.00 & 0.01 & 0.01 & 0.01 & 0.00 & 0.44 & $9.81 * * *$ \\
\hline Real estate, renting & 0.17 & 0.11 & 0.09 & 0.13 & 0.15 & $-2.57 * *$ & $-28.67 * * *$ \\
\hline Transport, storage an & 0.04 & 0.05 & 0.06 & 0.07 & 0.05 & 1.62 & $8.87 * * *$ \\
\hline Wholesale and retail & 0.30 & 0.23 & 0.18 & 0.14 & 0.27 & $-7.29 * * *$ & $-23.57 * * *$ \\
\hline Geographic Area & & & & & & & \\
\hline Centre & 0.20 & 0.20 & 0.19 & 0.18 & 0.20 & $-2.39 * * *$ & 0.64 \\
\hline North-East & 0.22 & 0.25 & 0.28 & 0.29 & 0.24 & $4.72 * * *$ & $10.64 * * *$ \\
\hline North-West & 0.30 & 0.32 & 0.33 & 0.36 & 0.31 & 0.09 & $5.27 * * *$ \\
\hline South & 0.27 & 0.22 & 0.20 & 0.16 & 0.25 & $-2.78 * * *$ & $-16.75 * * *$ \\
\hline $\begin{array}{l}\text { employment share } \\
\text { firm share }\end{array}$ & $\begin{array}{l}0.11 \\
0.64\end{array}$ & $\begin{array}{l}0.16 \\
0.24\end{array}$ & $\begin{array}{l}0.07 \\
0.05\end{array}$ & $\begin{array}{l}0.66 \\
0.07\end{array}$ & & & \\
\hline Observations (N) & 78,654 & 29,850 & 5,584 & 8,238 & 122,326 & & \\
\hline
\end{tabular}

Note: Balanced Panel 2008-2009.

Source: Authors' elaboration from data of Ministry of Labour, INPS, ISTAT. 


\section{The empirical strategy}

This section describes the regression discontinuity design used in this paper to assess the causal effects of employment protection on labour market outcomes. We use three formal tests to demonstrate that the regression discontinuity approach is appropriate in the present context. The section also puts forward a more elaborate identification strategy that embeds the regression discontinuity approach in a difference-in-differences framework.

\subsection{The regression discontinuity design $(R D D)$}

The econometric analysis in this paper exploits the fact that in Italy employment protection provisions for the individual dismissal of a regular worker vary significantly according to firm size, and thus provide a natural application for a regression discontinuity design (RDD). The main idea of RDD is that individuals firms in this case - just below the threshold provide a good counterfactual for those just above the threshold (the "treated"). The main advantage of RDD in comparison with other non-experimental approaches is that it relies on relatively weak assumptions (Hahn, Todd and Van der Klaauw, 2001; Lee and Lemieux, 2010) and, consequently, provides more credible results. Moreover, the assumptions are testable in a similar manner as in randomised experiments. ${ }^{16}$

In order to estimate the causal impact of employment protection, we will present both graphical and regression-based results. The graphical analysis consists of plotting the local averages of the outcome of interest within narrow firm's size intervals ('bins'). In the present context, bins are defined as intervals of 0.1 employees. ${ }^{17}$ However, since the graphical analysis is entirely non-parametric, it does not allow controlling for the independent effect of firm size. ${ }^{18}$ We therefore complement the non-parametric analysis with ordinary least squares estimates based on the following general parametric model:

$$
\begin{gathered}
Y_{i}=\sum_{n=0}^{N} \alpha_{0 n}\left(T-F_{i}\right)^{n}+D_{i} \sum_{n=0}^{N}\left(\alpha_{1 n}-\alpha_{0 n}\right)\left(F_{i}-T\right)^{n}+\beta X_{i}+\varepsilon_{i} \\
D_{i}=1\left[F_{i}>T\right] \\
T-h \leq F_{i} \leq T+h
\end{gathered}
$$

\footnotetext{
16 In particular, the conditional independence assumption is trivially satisfied in a RDD, whereas it is generally considered to be a strong assumption in other non-experimental contexts (Lee and Lemieux, 2010).

17 It is appropriate to define bins of less than one employee in the present case because employment is measured in full-time equivalents and thus represents a continuous variable.

$18 \quad$ Covariates can be taken into account by first regressing the outcome variable of interest on the covariates and plotting the local averages of the residual.
} 
where $Y$ refers to the outcome variable of interest in firm $i$; $F$ refers to level of dependent employment and $T$ the employment threshold set in the EP legislation (i.e. 15); $D$ a treatment dummy that equals 1 if dependent employment is larger than the threshold and zero otherwise; $X$ represents a vector of predetermined control variables - expressed in terms of the deviation from their sample means among large firms - to reduce the sampling variability of our RDD estimator. The $\alpha$ 's represent the key parameters to be estimated with the first subscript indicating whether it refers to untreated (0) or treated (1) observations and the second to $n$, which indicates the order of the polynomial in firm size. $\varepsilon_{i}$ represents a white-noise error term. The calculation of the standard errors takes account of the stratified nature of our data.

Equation (1) encompasses a wide variety of different specifications. If $\mathrm{N}=0$, equation (1) reduces to a non-parametric comparison of the means around the threshold: $Y_{i}=\alpha_{0 n}+\left(\alpha_{1 n}-\alpha_{0 n}\right) D_{i}+\varepsilon_{i}$; if $\mathrm{N}=1$, it reduces to a local linear specification and if $\mathrm{N}>1$ it represents a parametric specification with a polynomial of order $\mathrm{N}\left(\mathrm{N}_{\max }=3\right)$. Restricting the slopes to be the same on each side of the threshold is tantamount to equating $\alpha_{1 n}$ to $\alpha_{0 n}$ for $n \geq 1 . h$ refers to the window around the threshold (or bandwidth) and may take the value of 10,8 or 6 .

Equation (1) yields unbiased estimates as long as the behavioural assumption that firms do not "precisely" manipulate the assignment variable around the threshold is valid. Using the definition of "not precise" given in Lee and Lemieux (2010), this is the case when the density of the assignment variable is continuous conditional on all other observable and unobservable characteristics of firms that affect the outcome variable of interest. Importantly, this assumption yields the prediction that the treatment is locally randomised. Whether or not this assumption is valid can be empirically verified using a variety of different tests. This is done in the next sub-section.

\subsection{Assessing the validity of the $R D D$ in the present context}

In order to assess the validity of the RDD approach in the present context, we conducted three different tests. We first performed the standard test in the RDD literature of the assumption that the firmsize density is continuous around the EP threshold, as proposed by McCrary (2008). Since this test has low power if selection takes place on each side of the threshold, we also assess whether firms just below and above the threshold differ in their propensity to grow, as was done in Schivardi and Torrini (2008). Third, we conduct a series of balancing tests to assess to what extent firms just above and below the threshold differ in terms of their observable characteristics.

The key behavioural assumption of our RDD is that firms do not manipulate the assignment variable, in our case the number of employees in the firm. This requires the distribution of the assignment variable 
to be continuous for each firm. Since we only observe a single observation of the assignment variable for each firm at a given point in time, we cannot test this assumption directly. However, we can test whether it holds on average by testing whether the aggregate distribution of the assignment variable is continuous.

McCrary (2008) proposes a two-step procedure to test whether the aggregate distribution of the assignment variable is continuous. The first step involves the discretization of the assignment variable in a certain number of bins of the same width and computing the corresponding frequencies. This allows constructing a histogram of the assignment variable which gives a useful first indication of importance of manipulation. This is represented in Panel A of Figure 2. A visual inspection does not suggest any significant discontinuity in the firm-size distribution around the threshold. The second step consists of running local linear regressions of the computed frequencies on each side of the threshold. The regressions are weighted, with most weight being given to bins nearer to the threshold. The discontinuity is evaluated on the basis of the implied log difference in frequencies at the threshold (T) from the two regressions. Given the bin size, the optimal bandwidth, which defines the observations included in the regressions, is determined in order to obtain the best possible approximation of the density function. We use a bin size of 0.1 as in the non-parametric analysis. The results are reported in Panel B of Figure 2The dots indicate the computed frequencies at the midpoint of each bin, while the dashed bold lines correspond to the predictions of the weighted local linear regressions at each side of the threshold. Neither visual inspection, nor the estimated coefficients suggest a significant discontinuity at the threshold of 15 employees. The log difference is 0.045 with a standard error $0.047 .^{19}$

19 In the context of the differences-in-differences framework discussed in Section 4.3, we repeat the McCrary test industry-by-industry. 
Figure 2. McCrary test of the continuity of the employment density around the threshold Panel A. Firm-size distribution

Panel B. McCrary test (binsize $=0.1$; optimal bandwidth)

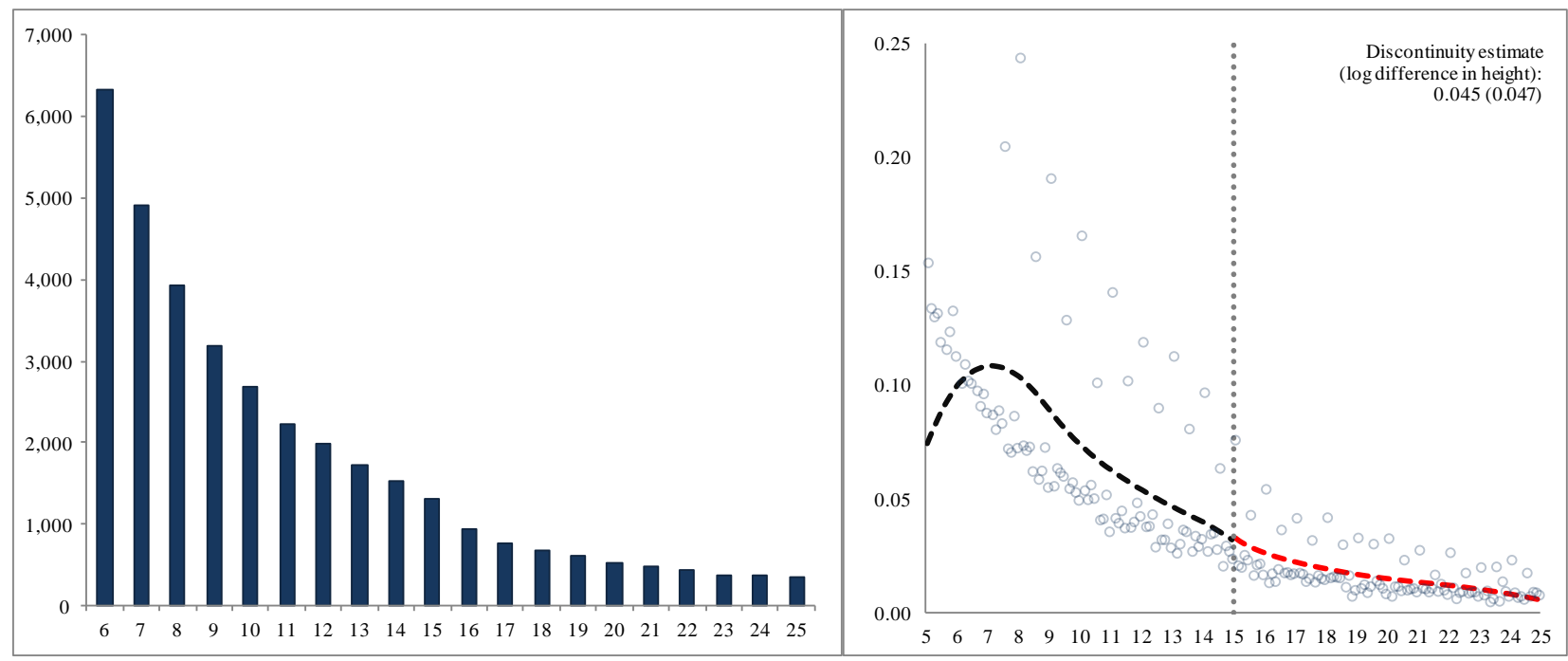

Since the McCrary test is based on the aggregate and not on the individual distribution of the assignment variable, it has low power when selection is not monotonic but occurs in both directions. It is not straightforward why small firms would want to sort above the threshold in response to employment protection rules and, therefore, we do not expect this to be an important issue in the present context. ${ }^{20}$ However, in order to show that this is indeed true we conduct two further tests.

Following Schivardi and Torrini (2008), we assess the impact of employment protection provisions on the propensity to grow. This is done by means of a probit model that specifies the probability of growing $P\left(F_{i t}>F_{i t-1}\right)$ as a function of a fourth-order polynomial of its initial employment level, $F_{i t-1}^{j}$, and a set of bin dummies with binsize one for firms with employment levels just below the threshold, $D^{K}$, and a set of controls, $X$.

$$
\begin{gathered}
P\left(F_{i t}>F_{i t-1}\right)=\alpha+\sum_{j=1}^{4} \beta_{j} F_{i t-1}^{j}+\sum_{k=1}^{K} \gamma_{k}\left(1-D_{i t-1}\right) D_{i t-1}^{K}+\beta X_{i t}+\epsilon_{i t}(2) \\
D_{i t-1}=1\left[F_{i t-1}>T\right] \\
D_{i t-1}^{K}=1\left[K-0.5 \leq F_{i t-1}<K+0.5\right] \text { for } K=5, . ., 25
\end{gathered}
$$

$20 \quad$ One possible hypothesis could be that firms self-select above the threshold because they want to signal to workers that open-ended contracts are well protected. This may induce workers to make more important investments in firm-specific human capital. 
The fourth-order polynomial in initial employment is assumed to capture the relationship between employment size and the probability to grow if employment protection provisions for large firms were to be extended to small firms. The coefficients on the bin dummies for firms with initial employment levels below the threshold, $\gamma_{k}$, may be interpreted as the threshold effect of employment protection on the probability to grow. The results are reported in Figure 3. Consistently with Schivardi and Torrini (2008), Leonardi and Pica (2010), Garibaldi and Pacelli (2004), we find that the probability to grow is increasing with respect to the firm size. We also find a lower probability of growth at 15 employees. However, in our case, the difference in the probability is not statistically different from zero.

Figure 3. Actual and predicted growth probabilities by firm size

2008-2009

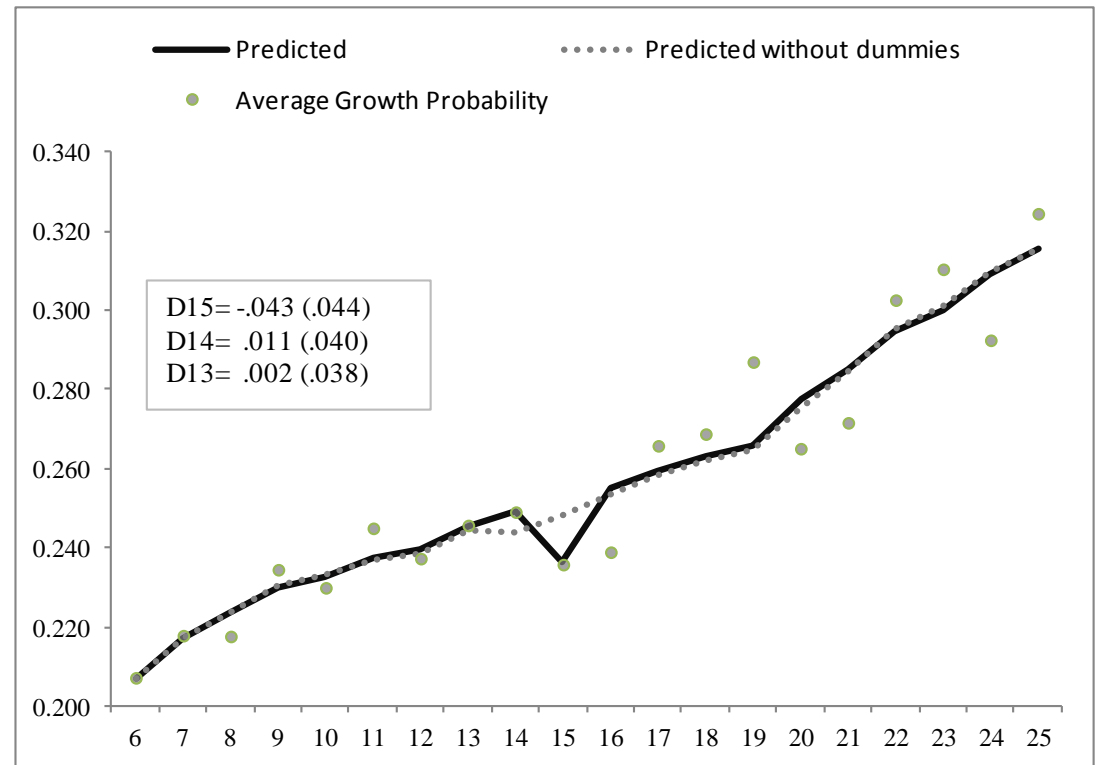

As a final test to assess the validity of the RDD in the present context, we assess whether the baseline covariates are locally balanced on either side of the threshold. This condition should be met if, as assumed in the RDD, the assignment variable can be considered as good as random around the threshold. Indeed, in the context of a valid RDD including any baseline covariates in the regressions should not affect the econometric estimates apart from the standard errors. We consider the following covariates: age of firms, region, industry and the number of workers involved in the short-time working scheme (CIG) as a share of employees. We check whether the two groups are balanced by replacing the dependent variable in equation (1) by each of the covariates, whilst using $\mathrm{N}=1,2,3$ and $\mathrm{h}=6,8,10$. The results, reported in the Table 2 below, show that there are generally no significant discontinuities at the 15 employee threshold. While some of the estimated coefficients are statistically significant, for no variable, except mining, are more than 
half of coefficients statistically significant at $5 \%$. The results for the mining sector rely on a relatively small number of observations which may not be sufficient to give a precise representation of the firm-size distribution. ${ }^{21}$ Our preferred specification based on $\mathrm{h}=10$ and $\mathrm{N}=3$ yields only one other variable apart from mining (financial sector) that is statistically significant at the $5 \%$ level.

Table 2. Balancing test for covariates

\begin{tabular}{|c|c|c|c|c|c|c|c|c|c|}
\hline \multirow{2}{*}{$\begin{array}{l}\text { Bandwidth } \\
\text { Order of polynomial }\end{array}$} & \multicolumn{3}{|c|}{$6-25$} & \multicolumn{3}{|c|}{$8-23$} & \multicolumn{3}{|c|}{$10-21$} \\
\hline & 1 order & 2 order & 3 order & 1 order & 2 order & 3 order & 1 order & 2 order & 3 order \\
\hline STW take up rate & $\begin{array}{l}-0.005 \\
{[0.006]}\end{array}$ & $\begin{array}{c}0.001 \\
{[0.009]}\end{array}$ & $\begin{array}{c}0.010 \\
{[0.012]}\end{array}$ & $\begin{array}{l}-0.002 \\
{[0.007]}\end{array}$ & $\begin{array}{c}0.006 \\
{[0.010]}\end{array}$ & $\begin{array}{c}0.005 \\
{[0.013]}\end{array}$ & $\begin{array}{c}0.004 \\
{[0.008]}\end{array}$ & $\begin{array}{c}0.003 \\
{[0.011]}\end{array}$ & $\begin{array}{l}-0.002 \\
{[0.016]}\end{array}$ \\
\hline Age & $\begin{array}{l}-0.522 \\
{[0.346]}\end{array}$ & $\begin{array}{l}-0.566 \\
{[0.511]}\end{array}$ & $\begin{array}{c}-1.163^{*} \\
{[0.683]}\end{array}$ & $\begin{array}{l}-0.414 \\
{[0.385]}\end{array}$ & $\begin{array}{l}-0.919 \\
{[0.573]}\end{array}$ & $\begin{array}{l}-1.133 \\
{[0.763]}\end{array}$ & $\begin{array}{l}-0.831^{*} \\
{[0.439]}\end{array}$ & $\begin{array}{l}-0.762 \\
{[0.654]}\end{array}$ & $\begin{array}{l}-1.133 \\
{[0.886]}\end{array}$ \\
\hline Construction & $\begin{array}{l}0.024 * * \\
{[0.010]}\end{array}$ & $\begin{array}{c}0.012 \\
{[0.015]}\end{array}$ & $\begin{array}{c}0.013 \\
{[0.021]}\end{array}$ & $\begin{array}{l}0.022 * * \\
{[0.011]}\end{array}$ & $\begin{array}{c}0.011 \\
{[0.017]}\end{array}$ & $\begin{array}{c}0.003 \\
{[0.023]}\end{array}$ & $\begin{array}{c}0.021 \\
{[0.013]}\end{array}$ & $\begin{array}{l}-0.000 \\
{[0.020]}\end{array}$ & $\begin{array}{c}0.009 \\
{[0.027]}\end{array}$ \\
\hline Manufacturing & $\begin{array}{c}-0.027^{* *} \\
{[0.014]}\end{array}$ & $\begin{array}{l}-0.017 \\
{[0.020]}\end{array}$ & $\begin{array}{l}-0.033 \\
{[0.028]}\end{array}$ & $\begin{array}{l}-0.024 \\
{[0.015]}\end{array}$ & $\begin{array}{l}-0.017 \\
{[0.023]}\end{array}$ & $\begin{array}{l}-0.045 \\
{[0.031]}\end{array}$ & $\begin{array}{l}-0.018 \\
{[0.017]}\end{array}$ & $\begin{array}{l}-0.024 \\
{[0.026]}\end{array}$ & $\begin{array}{c}-0.078 * * \\
{[0.036]}\end{array}$ \\
\hline Real estate & $\begin{array}{l}-0.002 \\
{[0.008]}\end{array}$ & $\begin{array}{c}0.005 \\
{[0.012]}\end{array}$ & $\begin{array}{c}0.004 \\
{[0.016]}\end{array}$ & $\begin{array}{c}0.002 \\
{[0.009]}\end{array}$ & $\begin{array}{c}0.002 \\
{[0.013]}\end{array}$ & $\begin{array}{c}0.005 \\
{[0.018]}\end{array}$ & $\begin{array}{c}0.003 \\
{[0.010]}\end{array}$ & $\begin{array}{l}-0.000 \\
{[0.015]}\end{array}$ & $\begin{array}{c}0.016 \\
{[0.020]}\end{array}$ \\
\hline Transport & $\begin{array}{c}-0.003 \\
{[0.006]}\end{array}$ & $\begin{array}{c}0.002 \\
{[0.010]}\end{array}$ & $\begin{array}{c}0.009 \\
{[0.013]}\end{array}$ & $\begin{array}{c}-0.003 \\
{[0.007]}\end{array}$ & $\begin{array}{c}0.007 \\
{[0.011]}\end{array}$ & $\begin{array}{c}0.011 \\
{[0.015]}\end{array}$ & $\begin{array}{c}0.000 \\
{[0.008]}\end{array}$ & $\begin{array}{c}0.008 \\
{[0.012]}\end{array}$ & $\begin{array}{c}0.020 \\
{[0.017]}\end{array}$ \\
\hline Wholesale & $\begin{array}{c}0.002 \\
{[0.011]}\end{array}$ & $\begin{array}{c}-0.002 \\
{[0.016]}\end{array}$ & $\begin{array}{c}0.007 \\
{[0.022]}\end{array}$ & $\begin{array}{c}-0.003 \\
{[0.012]}\end{array}$ & $\begin{array}{c}0.002 \\
{[0.018]}\end{array}$ & $\begin{array}{c}0.014 \\
{[0.024]}\end{array}$ & $\begin{array}{c}-0.004 \\
{[0.014]}\end{array}$ & $\begin{array}{c}0.010 \\
{[0.021]}\end{array}$ & $\begin{array}{c}0.014 \\
{[0.028]}\end{array}$ \\
\hline Hotel & $\begin{array}{c}0.011 * * \\
{[0.005]}\end{array}$ & $\begin{array}{c}0.007 \\
{[0.008]}\end{array}$ & $\begin{array}{c}0.014 \\
{[0.010]}\end{array}$ & $\begin{array}{l}0.011 * \\
{[0.006]}\end{array}$ & $\begin{array}{c}0.007 \\
{[0.008]}\end{array}$ & $\begin{array}{c}0.018 \\
{[0.012]}\end{array}$ & $\begin{array}{c}0.008 \\
{[0.006]}\end{array}$ & $\begin{array}{c}0.012 \\
{[0.010]}\end{array}$ & $\begin{array}{l}0.025^{*} \\
{[0.014]}\end{array}$ \\
\hline Electricity & $\begin{array}{c}-0.001 \\
{[0.001]}\end{array}$ & $\begin{array}{c}-0.000 \\
{[0.001]}\end{array}$ & $\begin{array}{c}0.001 \\
{[0.002]}\end{array}$ & $\begin{array}{c}-0.001 \\
{[0.001]}\end{array}$ & $\begin{array}{c}0.000 \\
{[0.002]}\end{array}$ & $\begin{array}{c}0.001 \\
{[0.002]}\end{array}$ & $\begin{array}{c}-0.000 \\
{[0.001]}\end{array}$ & $\begin{array}{c}0.000 \\
{[0.001]}\end{array}$ & $\begin{array}{c}0.001 \\
{[0.001]}\end{array}$ \\
\hline Mining & $\begin{array}{c}-0.005^{* * *} \\
{[0.002]}\end{array}$ & $\begin{array}{c}-0.004 \\
{[0.002]}\end{array}$ & $\begin{array}{c}-0.007 * * \\
{[0.003]}\end{array}$ & $\begin{array}{c}-0.004^{* *} \\
{[0.002]}\end{array}$ & $\begin{array}{c}-0.007 * * \\
{[0.003]}\end{array}$ & $\begin{array}{c}-0.001 \\
{[0.003]}\end{array}$ & $\begin{array}{c}-0.007 * * * \\
{[0.002]}\end{array}$ & $\begin{array}{c}-0.002 \\
{[0.003]}\end{array}$ & $\begin{array}{c}-0.001 \\
{[0.004]}\end{array}$ \\
\hline Financial & $\begin{array}{c}0.001 \\
{[0.002]}\end{array}$ & $\begin{array}{c}-0.004 \\
{[0.003]}\end{array}$ & $\begin{array}{c}-0.009 * * \\
{[0.004]}\end{array}$ & $\begin{array}{c}-0.001 \\
{[0.002]}\end{array}$ & $\begin{array}{l}-0.006 * \\
{[0.003]}\end{array}$ & $\begin{array}{c}-0.005 \\
{[0.004]}\end{array}$ & $\begin{array}{c}-0.003 \\
{[0.003]}\end{array}$ & $\begin{array}{c}-0.004 \\
{[0.003]}\end{array}$ & $\begin{array}{c}-0.007 * \\
{[0.004]}\end{array}$ \\
\hline North-east & $\begin{array}{c}0.005 \\
{[0.012]}\end{array}$ & $\begin{array}{c}0.003 \\
{[0.018]}\end{array}$ & $\begin{array}{c}0.009 \\
{[0.025]}\end{array}$ & $\begin{array}{c}0.003 \\
{[0.013]}\end{array}$ & $\begin{array}{c}0.003 \\
{[0.021]}\end{array}$ & $\begin{array}{c}0.025 \\
{[0.028]}\end{array}$ & $\begin{array}{c}0.001 \\
{[0.015]}\end{array}$ & $\begin{array}{c}0.010 \\
{[0.024]}\end{array}$ & $\begin{array}{c}0.033 \\
{[0.032]}\end{array}$ \\
\hline North-west & $\begin{array}{c}-0.038^{* * *} \\
{[0.013]}\end{array}$ & $\begin{array}{l}-0.030 \\
{[0.019]}\end{array}$ & $\begin{array}{l}-0.017 \\
{[0.026]}\end{array}$ & $\begin{array}{c}-0.043 * * * \\
{[0.014]}\end{array}$ & $\begin{array}{l}-0.012 \\
{[0.022]}\end{array}$ & $\begin{array}{l}-0.035 \\
{[0.029]}\end{array}$ & $\begin{array}{c}-0.034 * * \\
{[0.016]}\end{array}$ & $\begin{array}{l}-0.010 \\
{[0.025]}\end{array}$ & $\begin{array}{c}-0.060 * \\
{[0.033]}\end{array}$ \\
\hline Centre & $\begin{array}{c}-0.002 \\
{[0.011]}\end{array}$ & $\begin{array}{c}0.008 \\
{[0.016]}\end{array}$ & $\begin{array}{c}0.002 \\
{[0.022]}\end{array}$ & $\begin{array}{c}0.002 \\
{[0.012]}\end{array}$ & $\begin{array}{c}0.009 \\
{[0.018]}\end{array}$ & $\begin{array}{c}-0.007 \\
{[0.025]}\end{array}$ & $\begin{array}{c}0.006 \\
{[0.014]}\end{array}$ & $\begin{array}{c}-0.001 \\
{[0.021]}\end{array}$ & $\begin{array}{c}0.010 \\
{[0.028]}\end{array}$ \\
\hline South & $\begin{array}{c}0.035^{* * *} \\
{[0.011]}\end{array}$ & $\begin{array}{c}0.019 \\
{[0.017]}\end{array}$ & $\begin{array}{c}0.006 \\
{[0.023]}\end{array}$ & $\begin{array}{c}0.038 * * * \\
{[0.012]}\end{array}$ & $\begin{array}{c}0.001 \\
{[0.019]}\end{array}$ & $\begin{array}{c}0.017 \\
{[0.025]}\end{array}$ & $\begin{array}{l}0.027^{*} \\
{[0.014]}\end{array}$ & $\begin{array}{c}0.000 \\
{[0.022]}\end{array}$ & $\begin{array}{c}0.018 \\
{[0.029]}\end{array}$ \\
\hline Observations & 35,434 & 35,434 & 35,434 & 23,446 & 23,446 & 23,446 & 15,534 & 15,534 & 15,534 \\
\hline
\end{tabular}

21 Using a probit model instead of OLS in the context industry and region dummies yields very similar results. 
From the three different validity tests discussed above we conclude that manipulation of the assignment variable, i.e. firm selection, is not a major issue in the present context. While we cannot exclude the possibility that there is some sorting around the threshold, the three different tests consistently suggest that selection is not important and a RDD in the present context is therefore appropriate. ${ }^{22}$

\subsection{A difference-in-difference regression discontinuity design}

An important feature of RDD is that, as long as the treatment can be considered randomized around the threshold, controlling for any observed or unobserved characteristics does not affect the estimated size of the discontinuity at the threshold. Controlling for any observed or unobserved characteristics in this context may nevertheless be helpful for two reasons. First, to the extent that there are other regulations that make use of a firm-size threshold around 15, this could lead to a bias in our results. While other existing regulations do not use the same threshold definition as that used in the law for employment protection, there are regulations that make use of similar firm-size thresholds. A difference-in-difference framework can remove the role of such confounding factors by exploiting differences in the de jure or de facto stringency of employment protection that are unrelated to these other regulations (Grembi et al., 2012). Second, it may help to reduce remaining concerns about the role of manipulation of the assignment variable for the estimation of treatment effects as long as manipulation depends on being in one employment-protection regime or another and does not depend on the de jure or de facto difference in the stringency of employment protection. However, as was shown in the previous sub-section, manipulation does not appear to be a major concern in the present context. Third, using a DiD set-up can also help to increase the precision of our RDD estimates. This is most relevant when pre-treatment controls and posttreatment outcome variables are highly correlated, for example, due to the role of unobserved fixed effects.

The usual way to implement a difference-in-differences set-up is to focus on reforms that generate changes in the threshold effect before and after reforms. As our data do not allow focusing on reforms in EP, we propose to complement our RDD with a difference-in-differences estimator that exploits the differential role of employment protection provisions across industries characterized by different underlying needs to adjust the workforce. ${ }^{23}$ A number of studies (e.g. Haltiwanger et al., 2006, 2010;

\footnotetext{
22 Back-on-the-envelope calculations suggest that the share of missing firms above the threshold should be about $15 \%$ to entirely remove the difference in the incidence of temporary work between firms on both sides of the threshold. This calculation is based on asking how many firms with zero incidence of temporary work should be moved from the left to the right of the threshold in order to equalise the average incidence of temporary work. The various validation tests presented in this sub-section clearly suggest that selection is at best tiny and cannot remotely account for a share of missing firms of $15 \%$ above the threshold.

23 The difference-in-differences approach is motivated by previous work by Rajan and Zingales (1998) who uses the within-country variation to analyze the relationship between financial dependence and growth using a large cross-country dataset.
} 
Bassanini et al., 2009; and Cingano et al., 2010) have used similar approaches to analyze the role of employment protection on job and worker flows by exploiting the stylized fact that sectors differ in the needs for adjusting their workforces due to factors unrelated to employment protection such as underlying market and technological characteristics. The present analysis makes use of a similar idea by exploiting cross-sectoral differences in the volatility of employment to proxy for the market- and technology-driven need to adjust the workforce. ${ }^{24}$ Differences in market volatility across sectors may lead to important differences in the impact of employment protection since market volatility provides incentives for firms to adjust employment levels. Indeed, firms that operate in markets characterized by highly volatile output demand are likely to have a greater need to adjust employment levels and consequently are likely to be more strongly impacted by strict and costly EP provisions.

A major challenge is to come up with a measure of market volatility that differs across sectors but is not contaminated by the presence of employment protection. We proceed as follows. We start by measuring employment volatility for each firm as the standard deviation of log employment over the period 2001-2008. We then conduct a balancing test similar to the ones conducted above to assess whether firms just above and below the threshold differ in their levels of employment volatility using equation (1). The results indicate that employment volatility is slightly lower for firms just above the threshold. In principle, this could reflect the possibility that employment protection negatively influences the volatility of employment. However, the difference is not statistically significant. In order to make sure that our measure of employment volatility is not affected by the presence of employment-protection provisions, we focus on the intrinsic employment volatility by netting out the potential effect of employment protection on employment volatility for firms with employment levels above 15. Finally, we average our measure of intrinsic employment volatility across firms in each two-digit industry to obtain a measure of the intrinsic volatility of the sector in which firms operate.

In order to combine our RDD with a difference-in-differences approach, we extend equation (1) as follows:

$$
\begin{gathered}
Y_{i}=\sum_{n=0}^{N} \alpha_{0 n}\left(T-F_{i}\right)^{n}+\sum_{n=0}^{N} \beta_{0 n}\left(F_{i}-T\right)^{n} V_{j}+D_{i} \sum_{n=0}^{N}\left(\alpha_{1 n}-\alpha_{0 n}\right)\left(T-F_{i}\right)^{n}+D_{i} \sum_{n=0}^{N}\left(\beta_{1 n}-\right. \\
\beta 0 n) T-F i n V j+\varepsilon i \\
D_{i}=1\left[F_{i}>T\right] \\
T-h \leq F_{i} \leq T+h
\end{gathered}
$$

$24 \quad$ Using administrative data on workers in Italy for the period 1986-1995, Kugler and Pica (2008) use a similar approach to analyse whether the impact of employment protection is stronger in more volatile sectors. 
where $V_{j}$ refers to our measure of intrinsic sector volatility. ${ }^{25}$ The coefficient $\beta_{00}$ gives the average change in the outcome variable of interest of small firms that is associated with a 1 percent change in intrinsic sector volatility. The difference $\beta_{10}-\beta_{00}$ gives the difference-in-differences effect of employment protection, that is, it gives the differential response to a one percentage point change in intrinsic market volatility across small and large firms.

A key assumption of our difference-in-differences strategy is that the variation in the impact of employment protection across sectors, and, hence, intrinsic sector volatility is independent of the variation due to self-selection into size groups across sectors. In order to examine the validity of this assumption, we implement the McCrary and Schivardi-Torrini tests discussed above by industry. While the difference-indifference analysis is conducted at the 2-digit industry level, we report results by 1-digit industry in Table 3 to maintain reasonable cell sizes and for ease of presentation. The McCrary test statistic is statistically significant at the $10 \%$ in only one case (e.g. manufacturing), but it has the wrong sign suggesting that firms sort above rather than below the threshold. The results from the Schivardi and Torrini test tend to be negative suggesting that employment protection may reduce the probability of growing among firms just below the threshold, but tends to be statistically insignificant except in the real estate and wholesale sectors. All in all, the results suggest that complementing the RDD with the difference-in-differences approach described above is appropriate.

Table 3. McCrary test and Schivardi-Torrini test by 1-digit industry

\begin{tabular}{|c|c|c|c|c|c|c|}
\hline & \multirow[t]{2}{*}{ Volatility } & \multicolumn{2}{|c|}{ McCrary test } & \multicolumn{3}{|c|}{ Schivardi-Torrini } \\
\hline & & $\begin{array}{l}\text { Estimated } \\
\text { log diff. }\end{array}$ & $\begin{array}{c}\text { Standard } \\
\text { error }\end{array}$ & $\begin{array}{c}\text { Dummy } \\
\text { at } 15\end{array}$ & & \\
\hline Construction & 0.249 & 0,065 & 0,108 & 0,066 & 0,102 & \\
\hline Electricity, gas and water supply & 0.238 & 0,266 & 0,823 & na & na & \\
\hline Financial intermediation & 0.249 & $-0,559$ & 0,889 & $-0,091$ & 0,413 & \\
\hline Hotels and restaurants & 0.253 & 0,399 & 0,278 & $-0,202$ & 0,218 & \\
\hline Manufacturing & 0.244 & 0,039 & $0,066 *$ & $-0,045$ & 0,065 & \\
\hline Mining and quarrying & 0.244 & $-0,162$ & 0,842 & na & na & \\
\hline Real estate & 0.249 & 0,220 & 0,157 & $-0,288$ & 0,133 & ** \\
\hline Transport and communication & 0.246 & 0,370 & 0,207 & $-0,022$ & 0,173 & \\
\hline Wholesale & 0.250 & 0,107 & 0,147 & $-0,162$ & 0,092 & $*$ \\
\hline
\end{tabular}

NA. Not available: less than 200 firms in the industry with an employment size between 6-25.

25 The coefficient $\alpha_{00}$, represents the constant which either captures the average level of the outcome variable of interest for firms below the threshold when $\mathrm{N}=0$ or the level of the outcome variable evaluated at $\mathrm{F}=0$ when $\mathrm{N}>0$. Similarly, coefficient $\alpha_{10}$ gives the average level of the variable of interest for firms above the threshold for $\mathrm{N}=0$ or its level evaluated at $\mathrm{F}=$ when $\mathrm{N}>0$. The difference $\alpha_{10}-\alpha_{00}$ gives the discontinuity at the threshold. 


\section{Econometric results}

In the first part of this section, we report the RDD results, using a wide variety of different specifications with varying bandwidths and using alternatively linear, quadratic or third-order polynomials to control for the independent effects of firm size. In the second part, we conduct a series of robustness checks in order to test the sensitivity of our results.

\subsection{Baseline results}

Employment protection, worker reallocation and the incidence of temporary work

A number of previous studies have suggested that employment protection can have important adverse implications for worker reallocation. For example, Schivardi and Torrini (2008) find that employment protection does not reduce worker reallocation as it intends to do, but instead increases worker reallocation. Schivardi and Torrini (2008) argue that this perverse effect of employment protection (employment protection is supposed to increase job security) is likely to reflect the impact of employment protection on the incentives of firms to employ workers on temporary contracts. However, they or any other studies for Italy do not provide direct evidence that this is indeed the case.

In this sub-section, we provide a systematic evaluation of the impact of employment protection on excessive worker reallocation using the RDD approach set out in Section 4. Excessive worker reallocation is defined as twice the minimum of hires $(H)$ and separations $(S)$ over the average of firm employment:

$$
X R=\frac{2 \min (H, S)}{E} .
$$

The difference between total worker reallocation and excessive worker reallocation represents the net employment change. As it has been demonstrated in the previous section that employment protection does not affect employment growth, we focus directly on excessive worker turnover here. Figure 4 summarizes our RDD results of the impact of employment protection on excessive worker turnover. The figure shows that excessive worker turnover is substantially higher just above the threshold than in small firms just below the threshold, despite the presence of more stringent employment protection provisions in large firms. The parametric results, reported in Table 4, further show that these results are robust to using a wide variety of different specifications with varying bandwidths and using alternatively linear, quadratic or third-order polynomials to control for the independent effect of firm size. 
Figure 4. The impact of employment protection on excessive worker reallocation

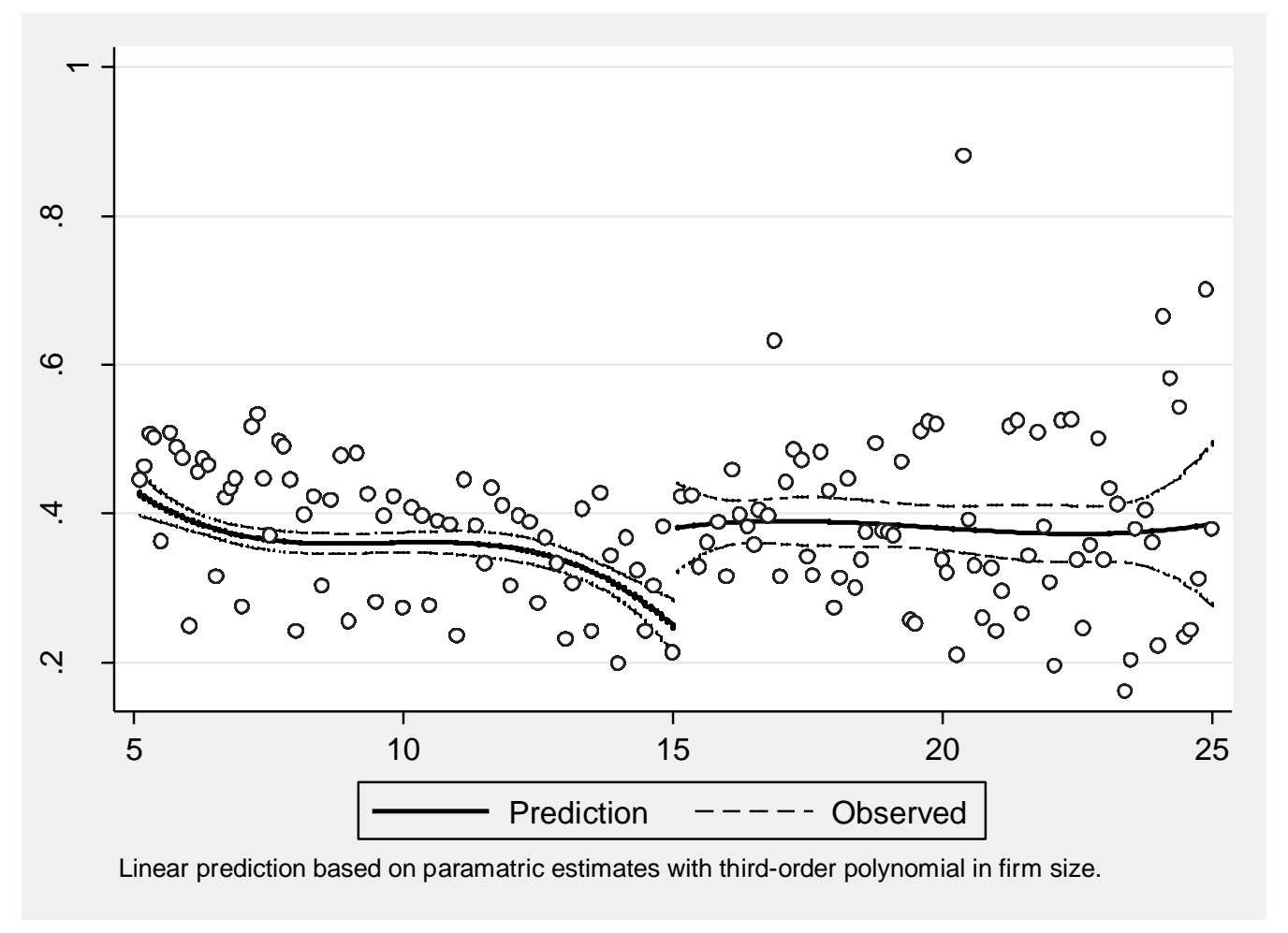

In addition to analyzing the impact of employment protection on worker turnover, we also provide direct evidence on each of its constituents using a shift-share decomposition of the difference in excessive worker turnover between small and large firms. This allows writing the differences in excessive worker turnover in terms of a between effect and a within effect as follows:

$$
\Delta \widehat{X R}=\sum_{i=1}^{N} \sum_{c=1}^{C} \Delta \hat{s}_{i c} \overline{X R}_{i c}+\sum_{i=1}^{N} \sum_{c=1}^{C} \bar{s}_{i c} \Delta \widehat{X R}_{i c}
$$

where $X R$ represents worker reallocation, $s$ the share in dependent employment of workers with contract type $c, \Delta$ hat to the estimated difference between large and small firms in the variable of interest that can be attributed to employment protection and bars the average values of large and small firms. The first term on the right-hand side gives the between component of excessive worker reallocation or the composition effect of employment protection. This term captures differences in excessive worker reallocation that can be attributed to differences in the composition of contracts between small and large firms. The second term captures the within component of excessive worker reallocation, or the technology effect of employment 
protection. This represents the differential impact of employment protection on excessive worker turnover by type of contract weighted by the average employment shares of each contract type.

The RDD results for the impact of employment protection on each component of excessive worker turnover are reported in Table 4. The RDD results indicate that the impact of employment protection on excessive worker reallocation largely reflects the impact of employment protection on the use of workers on temporary contracts (see also Figure 5). This result is robust to a number of different specifications: i) whether or not the incidence of temporary workers is measured in terms of dependent employment or permanent employment; ii) whether a linear, quadratic or third-order specification is used to control for firmsize; iii) for varying definitions of bandwidth. Our preferred estimates, based on bandwidth 6-25 and the use of a second-order polynomial in firm size, suggest that the discontinuity in employment protection increases the incidence of temporary work by 2.5 percentage points around the threshold. There is no evidence that employment protection also increases the use of independent contractors (either as a share of the total workforce or relative to the number of workers on permanent contracts) or has any impact on excessive worker reallocation by type of contract.

Figure 5. The impact of employment protection on the incidence of temporary employees

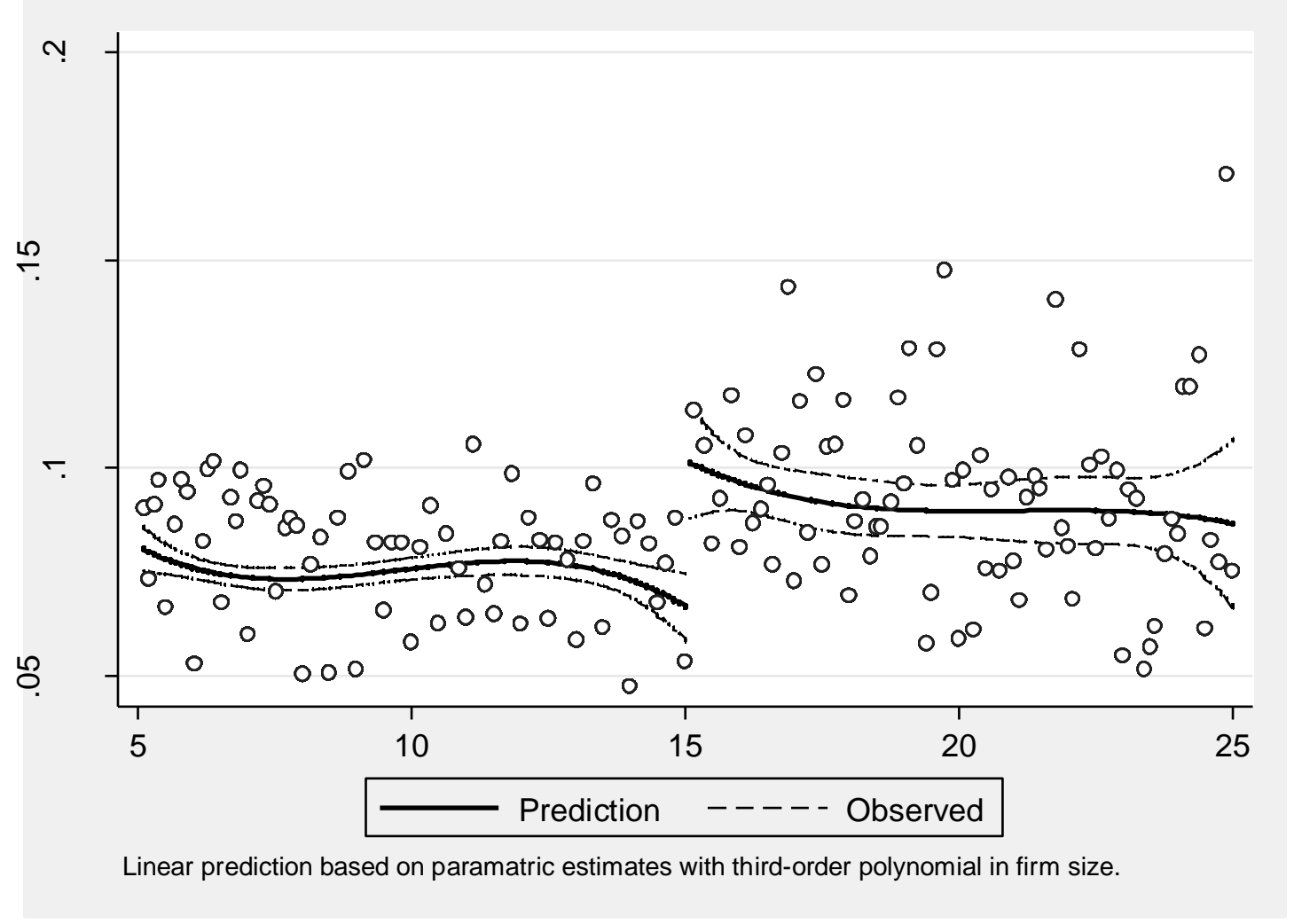


Table 4. Parametric estimates

\begin{tabular}{|c|c|c|c|c|c|c|c|c|c|}
\hline Bandwidth & & $6-25$ & & & $8-23$ & & & $10-21$ & \\
\hline Order of polynomial & 1 order & 2 order & 3 order & 1 order & 2 order & 3 order & 1 order & 2 order & 3 order \\
\hline $\begin{array}{l}\text { Excess worker reallocation rate } \\
\text { for all workers }\end{array}$ & $\begin{array}{c}0.070 * * * \\
{[0.015]}\end{array}$ & $\begin{array}{c}0.076^{* * *} \\
{[0.022]}\end{array}$ & $\begin{array}{c}0.099 * * * \\
{[0.029]}\end{array}$ & $\begin{array}{c}0.084^{* * *} \\
{[0.017]}\end{array}$ & $\begin{array}{c}0.072 * * * \\
{[0.024]}\end{array}$ & $\begin{array}{c}0.097 * * * \\
{[0.032]}\end{array}$ & $\begin{array}{c}0.094 * * * \\
{[0.018]}\end{array}$ & $\begin{array}{c}0.059 * * \\
{[0.027]}\end{array}$ & $\begin{array}{c}0.132 * * * \\
{[0.037]}\end{array}$ \\
\hline $\begin{array}{l}\text { Incidence of temporary work } \\
\text { of dependent employees }\end{array}$ & $\begin{array}{c}0.017 * * * \\
{[0.003]}\end{array}$ & $\begin{array}{c}0.020 * * * \\
{[0.005]}\end{array}$ & $\begin{array}{c}0.025 * * * \\
{[0.007]}\end{array}$ & $\begin{array}{c}0.019 * * * \\
{[0.004]}\end{array}$ & $\begin{array}{c}0.021 * * * \\
{[0.005]}\end{array}$ & $\begin{array}{c}0.028 * * * \\
{[0.007]}\end{array}$ & $\begin{array}{c}0.023 * * * \\
{[0.004]}\end{array}$ & $\begin{array}{c}0.019 * * * \\
{[0.006]}\end{array}$ & $\begin{array}{c}0.034 * * * \\
{[0.009]}\end{array}$ \\
\hline $\begin{array}{l}\text { Incidence of independent employees } \\
\text { of all employees }\end{array}$ & $\begin{array}{c}0.007^{* * *} \\
{[0.001]}\end{array}$ & $\begin{array}{c}0.000 \\
{[0.002]}\end{array}$ & $\begin{array}{r}-0.000 \\
{[0.003]}\end{array}$ & $\begin{array}{l}0.004 * * \\
{[0.002]}\end{array}$ & $\begin{array}{c}0.001 \\
{[0.002]}\end{array}$ & $\begin{array}{r}-0.000 \\
{[0.003]}\end{array}$ & $\begin{array}{c}0.002 \\
{[0.002]}\end{array}$ & $\begin{array}{c}0.001 \\
{[0.003]}\end{array}$ & $\begin{array}{c}0.000 \\
{[0.004]}\end{array}$ \\
\hline $\begin{array}{l}\text { Excess worker reallocation rate } \\
\text { for permanent employees }\end{array}$ & $\begin{array}{c}0.007 \\
{[0.005]}\end{array}$ & $\begin{array}{c}0.002 \\
{[0.007]}\end{array}$ & $\begin{array}{c}0.008 \\
{[0.009]}\end{array}$ & $\begin{array}{c}0.010^{*} \\
{[0.005]}\end{array}$ & $\begin{array}{l}-0.003 \\
{[0.008]}\end{array}$ & $\begin{array}{c}0.013 \\
{[0.010]}\end{array}$ & $\begin{array}{c}0.007 \\
{[0.006]}\end{array}$ & $\begin{array}{c}0.001 \\
{[0.009]}\end{array}$ & $\begin{array}{c}0.011 \\
{[0.012]}\end{array}$ \\
\hline $\begin{array}{l}\text { Excess worker reallocation rate } \\
\text { for temporary employees }\end{array}$ & $\begin{array}{c}0.335 * * * \\
{[0.112]}\end{array}$ & $\begin{array}{l}0.275^{*} \\
{[0.158]}\end{array}$ & $\begin{array}{c}0.152 \\
{[0.207]}\end{array}$ & $\begin{array}{c}0.392 * * * \\
{[0.122]}\end{array}$ & $\begin{array}{c}0.205 \\
{[0.174]}\end{array}$ & $\begin{array}{l}-0.076 \\
{[0.230]}\end{array}$ & $\begin{array}{c}0.395^{* * *} \\
{[0.138]}\end{array}$ & $\begin{array}{r}-0.031 \\
{[0.199]}\end{array}$ & $\begin{array}{c}0.077 \\
{[0.267]}\end{array}$ \\
\hline $\begin{array}{l}\text { Excess worker reallocation rate } \\
\text { for independent employees }\end{array}$ & $\begin{array}{c}0.007 * * * \\
{[0.001]}\end{array}$ & $\begin{array}{c}0.000 \\
{[0.002]}\end{array}$ & $\begin{array}{r}-0.000 \\
{[0.003]}\end{array}$ & $\begin{array}{l}0.004 * * \\
{[0.002]}\end{array}$ & $\begin{array}{c}0.001 \\
{[0.002]}\end{array}$ & $\begin{array}{r}-0.000 \\
{[0.003]}\end{array}$ & $\begin{array}{c}0.002 \\
{[0.002]}\end{array}$ & $\begin{array}{c}0.001 \\
{[0.003]}\end{array}$ & $\begin{array}{c}0.000 \\
{[0.004]}\end{array}$ \\
\hline Log labour productivity & $\begin{array}{c}-0.063^{* * *} \\
{[0.024]}\end{array}$ & $\begin{array}{c}-0.057 \\
{[0.036]}\end{array}$ & $\begin{array}{c}-0.071 \\
{[0.047]}\end{array}$ & $\begin{array}{c}-0.072 * * * \\
{[0.026]}\end{array}$ & $\begin{array}{l}-0.049 \\
{[0.039]}\end{array}$ & $\begin{array}{l}-0.094^{*} \\
{[0.052]}\end{array}$ & $\begin{array}{c}-0.081 * * * \\
{[0.030]}\end{array}$ & $\begin{array}{l}-0.037 \\
{[0.045]}\end{array}$ & $\begin{array}{c}-0.144^{* *} \\
{[0.060]}\end{array}$ \\
\hline Observations & 35,434 & 35,434 & 35,434 & 23,446 & 23,446 & 23,446 & 15,534 & 15,534 & 15,534 \\
\hline
\end{tabular}

\section{Employment protection and labour productivity}

In the previous sub-section, we have provided evidence that firms tend to circumvent employment protection by substituting permanent for temporary workers. ${ }^{26}$ However, this does not necessarily mean that employment protection is costless to firms. While the use of temporary workers may allow firms to effectively circumvent the effect of EP on permanent workers, it may have detrimental effects on firm performance to the extent temporary workers are not as productive as permanent workers, even after controlling for differences in labour costs. This may result from individual characteristics as well as lower incentives to invest in the human capital of temporary workers and their motivation. Moreover, the greater use of temporary workers may help to circumvent the adverse impact of employment protection on external flexibility, it may not entirely remove it. As a result, employment protection may still hinder the

26 The finding not reported that EPL does not affect the volatility of labour productivity (i.e. labour hoarding) is also consistent with this 
flexibility of firms to respond to shocks and by raising the costs of restructuring or experimenting with new technologies and processes (within firm effect). ${ }^{27}$

We now use our RDD framework to analyse the impact of EP on labour productivity. Moreover, we also present regression results that condition out the effect of EP on labour productivity through its impact on the incidence of temporary work (not reported). The latter is done by including the incidence of temporary employment as an additional covariate. The results, reported in Table 4 and Figure 6, show that employment protection tends to have a negative effect on labour productivity, reducing it by 6 to $14 \%$. Our estimates for labour productivity are statistically significant in five of the nine specifications. Controlling for the incidence of temporary work or the rate of worker reallocation consistently reduces the estimated impact of EP on labour productivity (Annex Table A2). Comparing the estimated coefficients in the unconditional and conditional regressions suggests that the impact of EP on labour productivity that comes about through its impact on the incidence of temporary work or worker reallocation may be quite sizeable.

Figure 6. The impact of employment protection on labour productivity

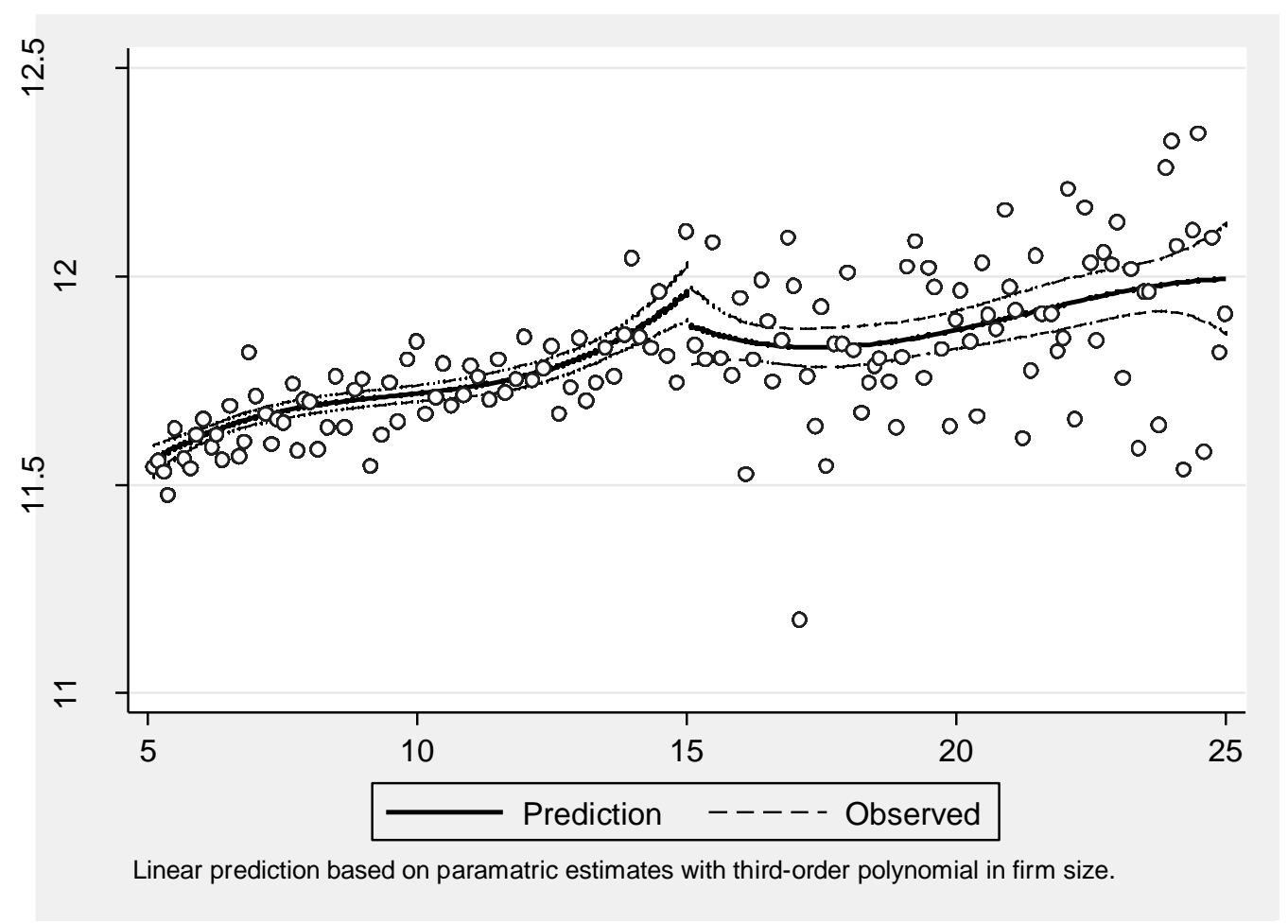

Table A3 in the Annex provides further results for our three outcome variables of interest, namely excess worker reallocation, the incidence of temporary work and labour productivity, for different sub-

$27 \quad$ In addition to these partial equilibrium effects, employment protection may also have implications for aggregate productivity by slowing the reallocation of resources from less to more productive firms. However, this latter channel is not captured by the RDD approach used in this paper. 
samples of firms. The results suggest that, in general, the effects of employment protection tend to be most pronounced among service firms, young firms and firms in the North-West of Italy. ${ }^{28}$ While the impact of EP on labour productivity is statistically significant in a number of sub-samples, Table A4 in the Annex shows that this comes entirely about through the impact of EP on temporary work or worker reallocation: after controlling for the role of the incidence of temporary work and worker reallocation on labour productivity (on both sides of the threshold), EP no longer has a statistically significant effect on labour productivity.

\subsection{Sensitivity analysis}

In order to check the sensitivity of our results for our three main outcome variables (excess worker reallocation, the incidence of temporary work and labour productivity), we conduct a number of further robustness tests. The results are reported in Table 5. All estimates include a third-order polynomial in firm size and make use of the window 5-25 ( $\mathrm{N}=3, \mathrm{~h}=10)$. Column 1 reports the baseline estimates as a benchmark (column 3 of Table 4). Column 2 reports the results based on a specification that imposes that the relationship between firm size and the outcome variable of interest is identical ("symmetric"). Column 3 reports the results that include a number of additional controls, including age, age squared, the take up rate of the short-time working scheme (Cassa Integrazione Guadagni), industry and region ("controls). Columns 4 and 5 report the results based on alternative measures of firm size used the literature. The results in column 4 are based on the measure of firm size used in Schivardi and Torrini (2008), while column 5 reports the result based on the measure of firm size used in Leonardi and Pica (2013). The second panel of Table 5 reports the results for the same set of specifications but using the RDD cum difference-in-differences framework.

- Excess worker reallocation. The results for excess worker reallocation are robust to all different specifications. They are quantitatively unaffected by the imposition of symmetry, the inclusion of controls and the measurement of firm size. Similar results are also obtained with the RDD cum differences-in-differences framework. Using DID-RDD, the coefficients are positive in all five specifications as in the baseline and statistically significant except in the specification that imposes symmetry.

- Incidence of temporary work. The results with respect to the incidence of temporary work are robust to all five RDD specifications. The results in columns 2 to 4 are slightly smaller than in the baseline (around 0.2), but much larger when using the Leonardi-Pica (2013) measure of

\footnotetext{
${ }^{28}$ The negative impact of employment protection on labour productivity is statistically significant among young firms and in the North-West.
} 
firm size. Similar results based on a second-order polynomial yield comparable results for the sign, except when using the Leonardi-Pica measure which yields a negative and statistically significant estimate, suggesting that this measure does not yield robust results in the present context.

- Labour productivity. The sensitivity analysis also suggests that EP tends to exert a negative impact on labour productivity, although a number of specifications yield statistically insignificant results.

Table 5. Sensitivity analysis

Third-order polynomial in firm size, bandwidth 5-25

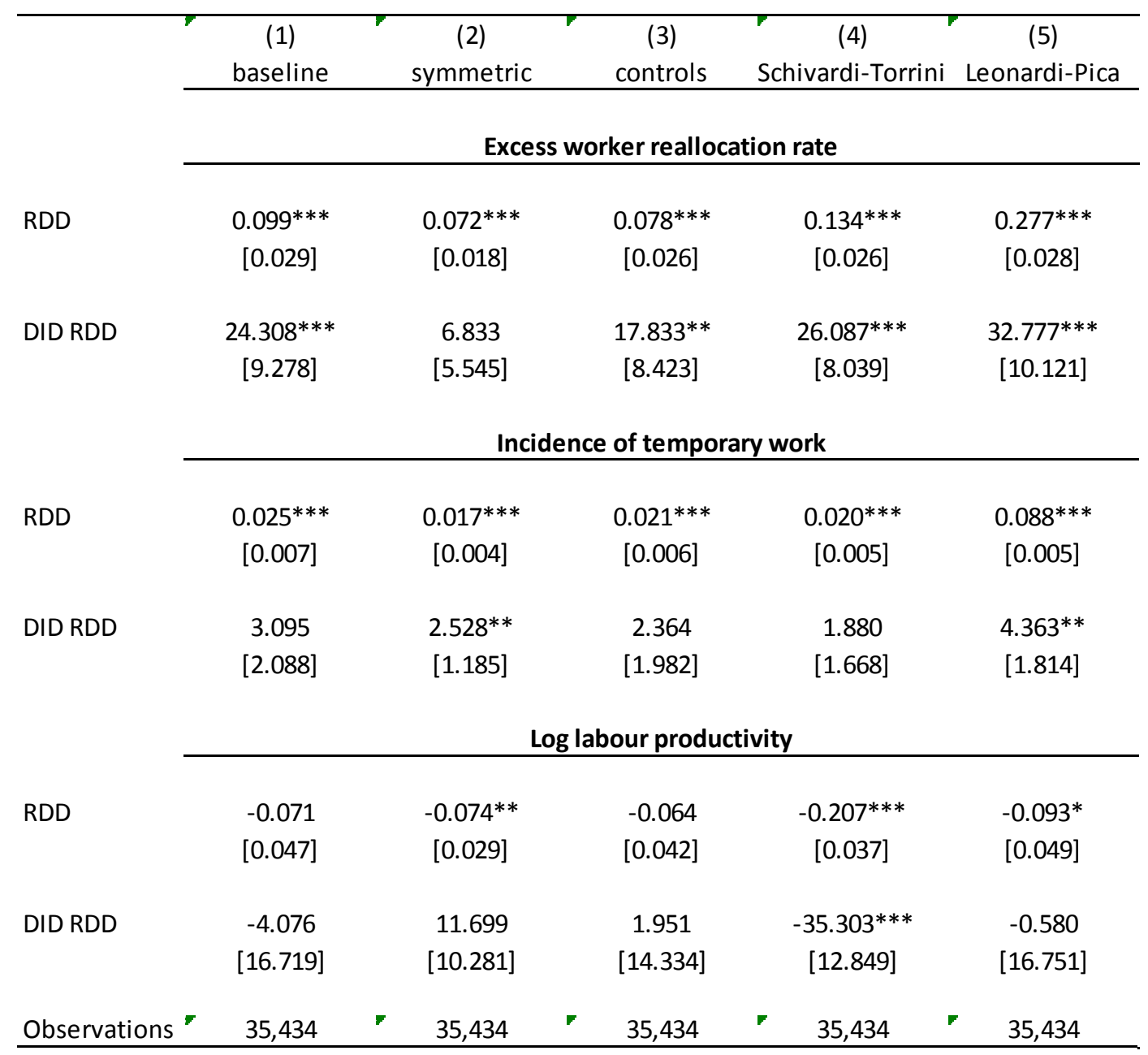

Standard errors in brackets, ${ }^{* * *} p<0.01,{ }^{* *} p<0.05,{ }^{*} p<0.1$

In addition, we implement placebo tests, by estimating average treatment effects on the treated using fake values of the threshold (where there should not be any effect). In particular, regarding the incidence of temporary employees, we look at all t-thresholds, for $9 \leq t \leq 14$. In other words, we focus on firms not 
affected by the employment threshold (Lalive et al., 2009). By using the baseline model, we consider the 95\% confidence interval and we do not find a significant discontinuity in any of these points (Figure 7).

Figure 7. Placebo tests - Estimating the treatment effect on the incidence temporary work at fake thresholds

Discontinuities calculated by quadratic model; bandwidth [T-4; T+4]

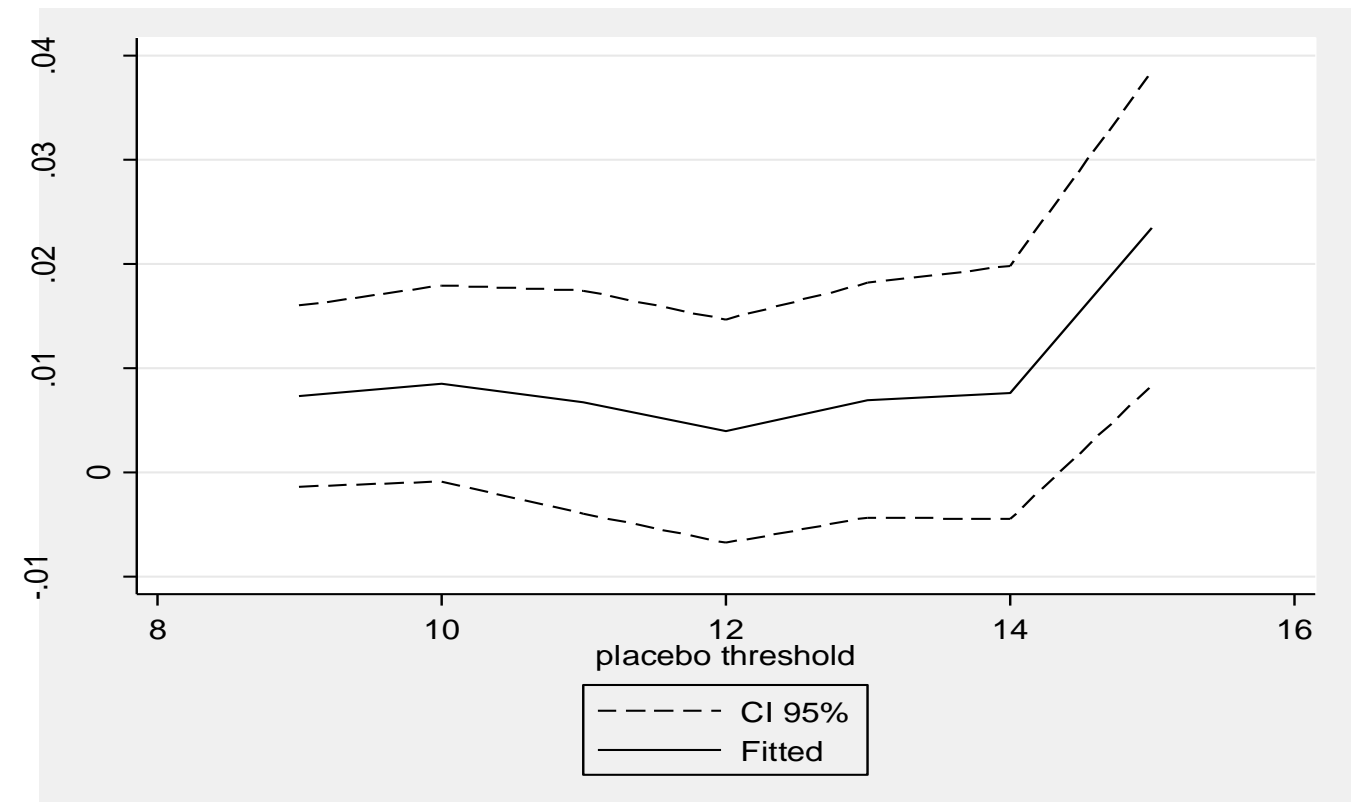

\section{The aggregate implications of employment protection}

The estimates that have been discussed so far relate to the average effect of the discontinuity in employment-protection provisions on firms above the threshold but with less than 25 employees. The estimates do not necessarily say anything about the impact of employment protection on the incidence of temporary work in firms with more than 25 employees. The main reason for this is that the sample of firms used in the analysis differs importantly in its characteristics from the population as a whole (see Table 1). This is an important limitation of the analysis so far since understanding the aggregate effects of employment protection on the economy-wide incidence of temporary work is key from a policy perspective.

The effect of EP on large firms not included in the analysis but which account for the bulk of employment may differ from that of firms around the threshold because of different factors. For example, EP may have a different impact on large firms because of differences in their production technology. To the extent that large firms rely more on firm-specific human capital, seek to limit worker turnover and pay 
higher wages, the scope to substitute permanent workers by workers on temporary contracts may be more limited. Moreover, large firms may differ in the way they respond to idiosyncratic and aggregate shocks. Because of their larger size it may be easier to downsize using natural attrition and reallocating worker between units. In addition, the exposure of large firms to output shocks may differ from that of firms around the threshold. While it is not straightforward to assess the role of these differences for the impact of $\mathrm{EP}$ on the incidence of temporary work, it is nevertheless plausible to assume that the aggregate impact of EP may not be as large as its impact around the threshold.

We start by analyzing the relationship between the incidence of temporary work and firm size. Panel A of Figure 8 presents the mean values of the incidence of temporary work by firm size as well as a fitted line based on a kernel-weighted local polynomial regression. It shows that the incidence of temporary work jumps around the threshold by about 1.5 percentage points from less than 8 to over 9 . This is somewhat smaller than our estimate of the discontinuity which tends to lie in the range of 2.0 to 2.5. Panel B shows the relationship between the incidence of temporary work and firm size from firms with three employees to firms with 500 employees. This shows that the relationship between firm size and the incidence of temporary work is largely constant. The fitted line hovers between 7 and $9 \%$ for firms from to 15 to 500 without any obvious pattern. The relative stability of the incidence of temporary work across firms of different sizes provides a first indication that the impact of EP is likely to persist across the distribution of large firms. 
Figure 8. The relationship between the incidence of temporary work and firm size

Panel A. Domain 3-50

Panel B. Domain 3-500

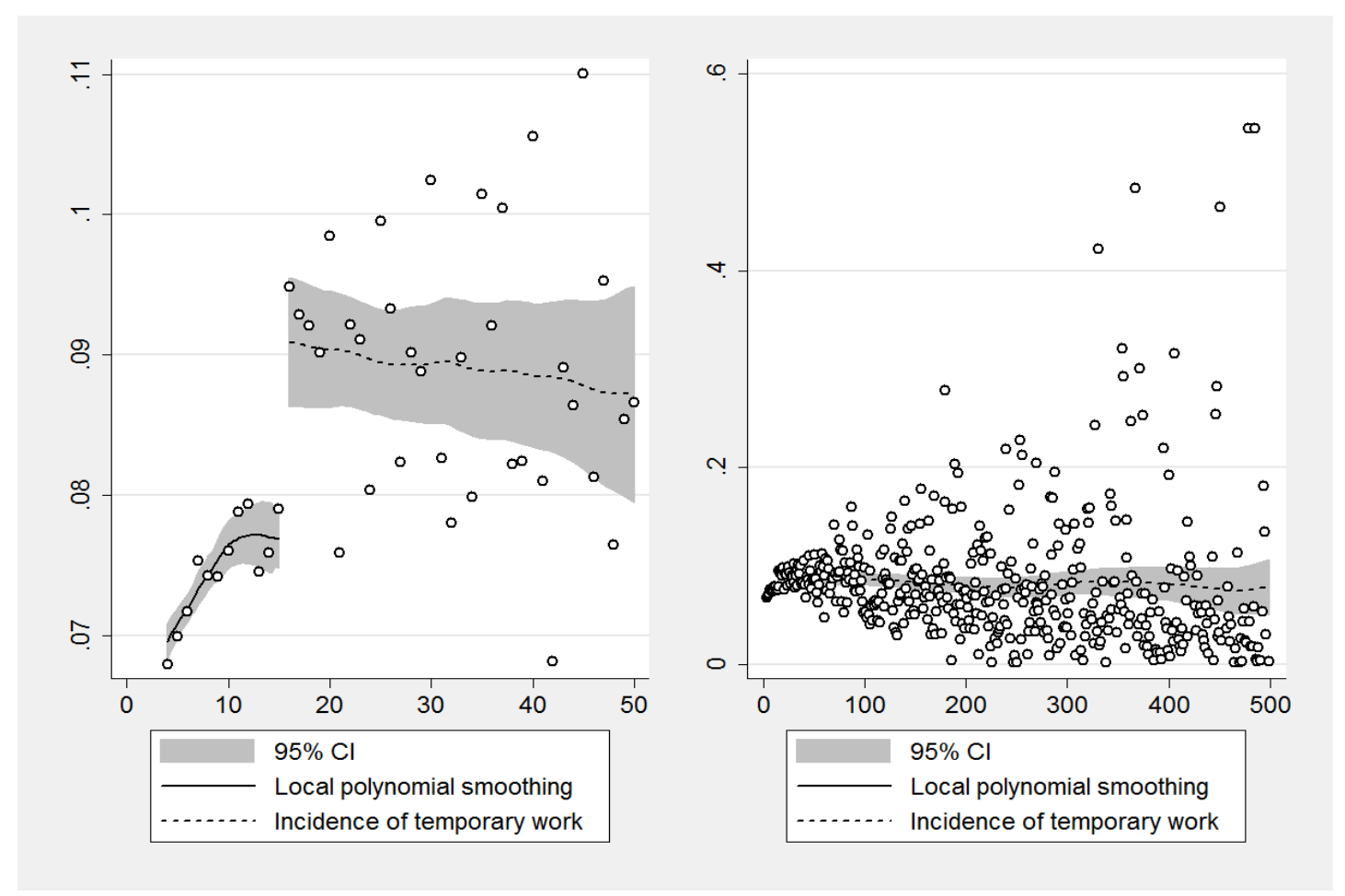

We address the issue more formally using semi-parametric estimates of the actual relationship between the incidence of temporary work and firm size and the counterfactual relationship had the employment-protection regime for small firms been applicable to all firms using the method recently proposed by Angrist and Mikkanen (2012). They argue that simply extrapolating from the parametric estimates discussed above in principle allows one to compare actual and counterfactual relationship. However, in practice, this method tends to be very sensitive to the specification of the parametric model. This is also the case in the present context. They therefore suggest an alternative method that involves using control variables to estimate counterfactual outcomes away from the cutoff under the assumption that treatment is conditionally independent of firm size.

In contrast to the conditional independence assumption (CIA) in the context of conventional quasiexperimental indicators, the CIA assumption invoked here exploits the deterministic nature of the way treatment is assigned in a RDD and, consequently, its validity can be tested by assessing whether the assignment variable has a statistically significant effect on potential outcomes conditional on the controls. The results of such validity tests are reported in Table A5 for three different bandwidths. They show that in only one of the six cases firm size has a statistically significant impact on the incidence of temporary work, 
conditional on controls. The largest bandwidth is used and the focus is on firms below the cutoff. This is not surprising as Figure 8 suggests a strong relationship between the incidence of temporary work and firm size among very small firms. However, close to the cutoff the incidence of temporary work does indeed appear to be independent of firm size conditional on controls. This means that we can use the controls to analyse the impact of employment protection on the incidence of temporary work for firms away from the cutoff.

Figure 9 shows the CIA estimates of the effect of employment protection on the incidence of temporary work based linear reweighted regression (Kline, 2011). The solid lines show the fitted lines of the observed incidence of temporary work conditional on the controls. The dashed line shows the counterfactual outcomes conditional on controls in the absence of the treatment. The results suggest that the average treatment effect on the treated does not vary significantly over the domain considered. ${ }^{29}$

Figure 9. CIA estimates of the incidence of temporary work bandwidth 5-25

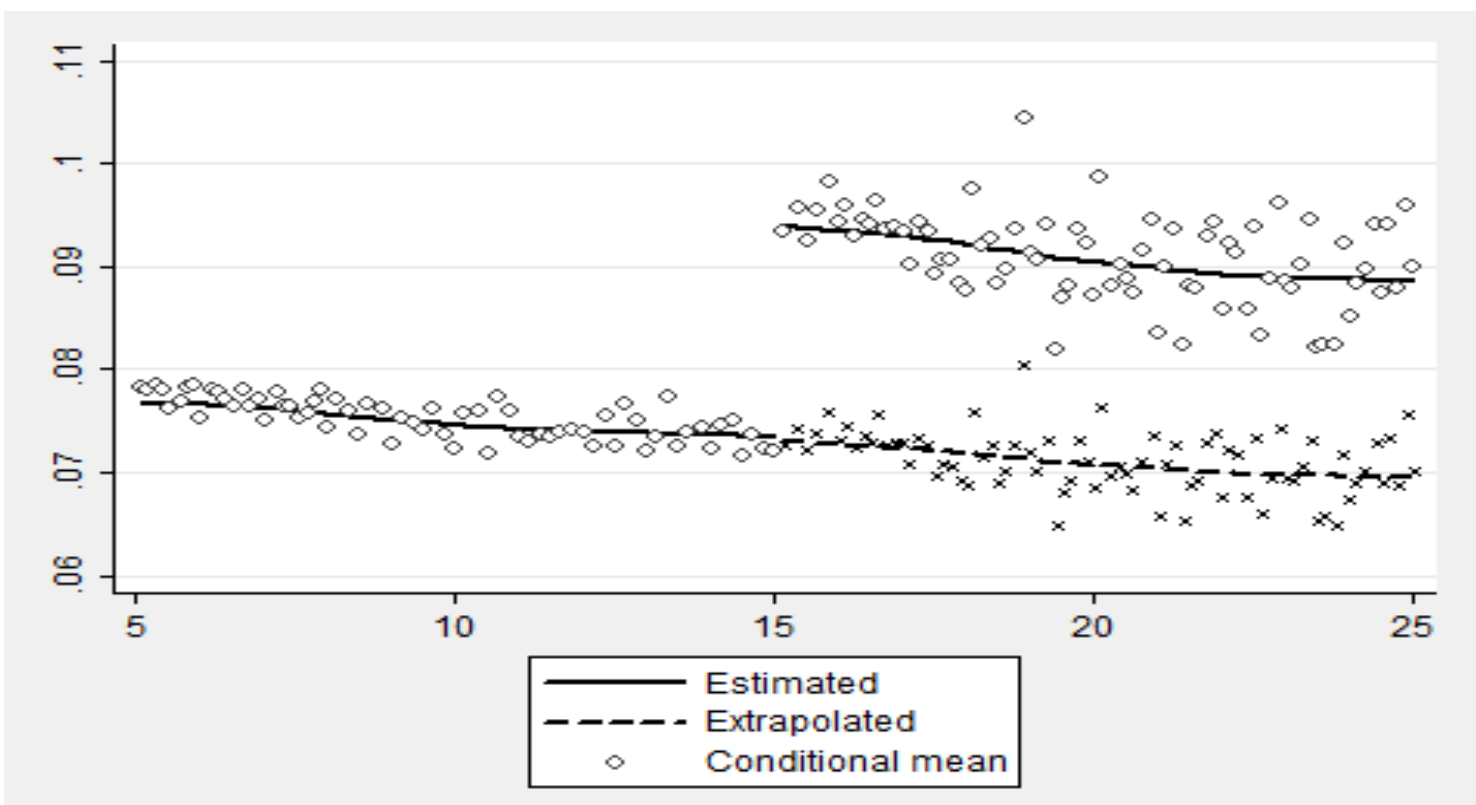

Estimated: Within-sample prediction based on estimates of the incidence of temporary work below the threshold; Extrapolated: Out-of-sample prediction above the threshold based on estimates of the incidence of temporary work below the threshold; Conditional mean: Conditional mean of the incidence of temporary work within employment-size bin based on estimates of the incidence below the threshold/over the entire domain, respectively.

$29 \quad$ We also used an alternative reweighting method which yields qualitatively similar results. In this case, we adopted a flexible parametric model that allowed treatment effects to vary by firm age, region and industry. Using the heterogeneous treatment effects in combination with the characteristics of the population of firms one can construct a re-weighted average treatment effect on the treated (ATT) that is more representative for the economy as a whole. Reweighting did not change the results significantly. 
We conclude that our RDD estimates do not just relate to the impact of EP around the cutoff but also apply to firms further away from the cutoff. While the formal estimates only considered firms with up to 25 employees, the stability of the relationship between the incidence of temporary work and firm size suggests that our estimates are also informative for firms well beyond the 25 mark. Taking our ATT at face value, this implies that the incidence of temporary work in firms with 15 or more employees would be $7 \%$ instead of the observed value of $9 \% .{ }^{30}$ Put differently, EP account for over $20 \%$ of the incidence of temporary work.

30 Note that these percentages refer to the firms with at least one permanent employee - the estimation sample. 


\section{Conclusions}

In this paper, we exploit a novel matched employer-employee dataset to investigate the impact of employment protection on firms' workforce behaviour in Italy. We adopt a regression discontinuity design that exploits the variation in employment protection provisions in Italy between firms below 15 employees and those above 15 employees. Before a recent reform (June, 2012) the Italian legislation imposed significantly higher dismissal costs, and greater uncertainly, in case of unfair individual dismissal for firms above the threshold compared with those below. The previous literature on the effect of the discontinuous change in legislation In Italy focused on the propensity to grow below and above the threshold and on the asymmetric expansion and contraction in workforce just below the threshold. In other words, the focus was on the potentially negative impact on employment growth in firms around the threshold. This literature generally found only a very modest, albeit statistically significant, lower propensity to grow for firms below the threshold.

Our newly firm-level dataset allows better identifying the size of firms and most importantly the different typologies of labour contracts and thus assessing the potential effect of the EP threshold not only on the propensity to grow but also on the composition of the workforce. Using these data, we show the firm-size density is actually continuous around the threshold, firms just below the threshold do not display an unusually low propensity to grow, and the available control variables are balanced around the threshold. This justifies the use of regression discontinuity design in the empirical analysis.

While not affecting the propensity to grow, employment protection significantly affects the composition of employment and, as a result, tends to dampen worker security in firms above the threshold. Indeed our empirical results provide clear evidence that that firms that decide to go beyond the threshold tend to resort more to temporary employment contracts to circumvent the stricter regulations on permanent contracts. In this way, they exploit the market opportunities and economies of scale offered by the larger size without incurring in extra adjustment costs in case of downsizing. Our preferred estimates suggest that the discontinuity of EP increases the incidence of temporary work by 2 to 2.5 percentage points (about $20 \%$ ) in firms above the threshold. Using the recently proposed method to identify the impact of treatment effects away the threshold by Angrist and Mikkanen (2012), we find that our RDD estimates do not just relate to the discontinuity around the threshold but also apply to larger firms well beyond the threshold.

In the paper we also assess whether the discontinuity of employment composition around the threshold results in a discontinuity in the productivity performance of firms. In particular, the greater use of temporary employment in firms above the threshold to overcome the otherwise much higher workforce adjustments costs has a negative impact of firm productivity. The effect is again sizeable, although there is 
some uncertainty about its precise magnitude. Importantly, a considerably part of the impact of EP on labour productivity appears to come through its impact on the incidence of temporary work (and hence worker reallocation). This means that the wide discrepancy in employment protection between workers on open-ended contracts and those on temporary and atypical contracts not only reduces job security on average, but also comes at a cost for employers in terms of lower labour productivity.

All in all, our results suggest that employment protection has a quantitatively sizeable impact on the incidence of temporary work and in turns, this tends to reduce rather than to increase job security and hinder labour productivity. While these results deserve further scrutiny, they clearly point to the potential costs of EP not just for the firms concerned but also the workers in these firms and for the overall labour market segmentation in Italy. In this context, the recent labour reforms, if fully implemented, by reducing the stringency and uncertainty of employment protection provisions for workers on permanent contracts for firms above the threshold, could contribute to better economic performance and tackle at least in part the large dualism in the Italian labour market. 


\section{References}

Angrist, J. and M. Rokkanen (2012), "Wanna get away? RD identification away from the cutoff”, NBER Working Paper, No. 18662.

Autor, D., W.R. Kerr and A.D. Kugler (2007), "Do Employment Protections Reduce Productivity? Evidence from US States", Economic Journal, Vol. 117, pp. F189-F217.

Baker, D. A. Glyn, D. Howell and J. Schmitt (2005), "Labour market institutions and unemployment: a critical assessment of the cross-country evidence", in D. Howell (ed.), Fighting Unemployment: the limits of free market orthodoxy, Oxford University Press, Oxford.

Bassanini, A. and R. Duval (2009), "Unemployment, Institutions, and Reform Complementarities: Re-assessing the Aggregate Evidence for OECD Countries", Oxford Review of Economic Policy, Vol. 25, pp. 40-59.

Bassanini, A., L. Nunziata and D. Venn (2009), "Job Protection Legislation and Productivity Growth in OECD Countries”, Economic Policy, Vol. 58, pp. 349-402.

Bentolila S., J. Dolado and J. Jimeno (2008), "Two-Tier Employment Protection Reforms: The Spanish Experience", CESifo DICE Report, Vol. 6 (4), pp. 49-56.

Blanchard, O. and J. Wolfers (2000), "The Role of Shocks and Institutions in the Rise of European Unemployment: The Aggregate Evidence", Economic Journal, Vol. 110, No. 462.

Boeri, T. and Garibaldi, P. (2007), “Two-Tier Reforms of Employment Protection: A Honeymoon Effect?”, Economic Journal, Vol. 117 (521), pp. 357-385.

Boeri, T. and J. Jimeno (2005), "The Effects of Employment Protection: Learning from Variable Enforcement", European Economic Review, Vol. 49, pp. 2057-2077.

Borgarello, A., P. Garibaldi and L. Pacelli (2004), "Employment Protection Legislation and the Size of Firms", Il Giornale degli Economisti, 63(1), pp. 33-66.

Bronzini, R., Iachini, E. (2011), “Are incentives for R\&D effective? Evidence from a regression discontinuity approach", Working papers Banca d'Italia, No.791.

Cingano, F., M. Leonardi, J. Messina and G. Pica (2010), "The effects of employment protection legislation and financial market imperfections on investment: evidence from a firm-level panel of EU countries", Economic Policy, Vol. 25, pp. 117-163.

Consalvi, M., Costanzo, L., Filipponi, F. (2008), "Evolution of Census Statistics on Enterprises in Italy 1996-2006: from the Traditional Census to a Register of Local Units”, Istat.

Fiori, G., G. Nicoletti, s. S. Scarpetta and F. Schiantarelli (2012), "Employment Outcomes and the Interaction Between Product and Labor Market Deregulation: Are They Substitutes or Complements?," Economic Journal, 122(558), pp. F79-F104.

Gal, P.N., A. Hijzen and Z. Wolf (2012), "The Role of Institutions and Firm Heterogeneity for Labour Market Adjustment: Cross-country Firm-level Evidence", OECD Social, Employment and Migration Working Papers, 2012/134. 
Grembi, V., T. Nannicini and U. Troaino (2012), "Policy Responses to Fiscal Restraints: A Difference-inDiscontinuities Design”, IZA Discussion Paper, No. 6952.

Hahn, J., Todd, P., Van der Klaauw, W. (1999), "Evaluating the effect of an antidiscrimination law using a regression-discontinuity design", NBER Working Paper, No. 7131.

Hahn, J., Todd, P., Van der Klaauw, W. (2001), "Identification and estimation of treatment effects with a regression-discontinuity design", Econometrica, Vol. 69Iss (1), pp. 201-209.

Haltiwanger, J., S. Scarpetta and H. Schweiger (2006) "Assessing Job Flows across Countries: The Role of Industry, Firm Size and Regulations”, IZA Discussion Paper No. 2450, Bonn.

Haltiwanger, J., S. Scarpetta and H. Schweiger (2010) ""Cross country differences in job reallocation: the role of industry, firm size and regulations," Working Papers 116, European Bank for Reconstruction and Development, Office of the Chief Economist.

Ichino, P. (1996), Il lavoro e il mercato, Mondadori.

Ichino, A., M. Polo and E. Rettore (2003), “Are Judges Biased by Labour Market Conditions”, European Economic Review, vol. 47, no. 5, pp. 913-944.

Imbens, G.W., Lemieux, T. (2008), "Regression discontinuity designs: a guide to practice", Journal of Econometrics, Vol. 142 (2), pp. 615-635.

Italian Ministry of Labour (2012): "Rapporto annuale sulle Comunicazioni Obbligatorie".

Kline, P. (2011), "Oaxaca-Blinder as a Reweighting Estimator", American Economic Review: Papers and Proceedings, Vol.101, pp. 532-537.

Kugler, A. D. (2004), "The Effect of Job Security Regulations on Labor Market Flexibility: Evidence from the Columbian Labor Market Reform," in Law and Employment: Lessons from Latin America and the Caribbean, ed. by J. J. Heckman, and C. Pages-Serra, Chicago University Press, Chicago.

Kugler, A.D. and G. Pica (2008), "Effects of Employment Protection on Worker and Job Flows: Evidence from the 1990 Italian Reform", Labour Economics, Vol. 15, No. 1, pp. 78-95.

Kugler, A., J.F. Jimeno and V. Hernanz (2003), "Employment Consequences of Restrictive Permanent Contracts: Evidence from Spanish Labor Market Reforms”, CEPR Working Paper No. 3724.

Lalive, R., J.P. Wuellrich, J. Zweimuller (2009), "Do financial incentives for firms promote employment of disabled workers? A regression discontinuity approach", The Austrian Center for Labor Economics and the Analysis of the Welfare State, Working Paper No. 0911.

Lee, D.S. and Lemieux, T. (2010), "Regression Discontinuity Design in Economics", Journal of Economic Literature, Vol. 48(2), pp. 281-355, June.

Leonardi, M. and G. Pica (2013), "Employment protection legislation and wages", Economic Journal, forthcoming.

Ludwig, J. and Miller, D.L. (2007), “Does head start improve children's life chances? Evidence from a regression discontinuity design", Quarterly Journal of Economics, 122 (1), pp. 159-208. 
McCrary, J. (2007), "Manipulation of the running variable in the regression discontinuity design: A density test", Journal of Econometrics, Vol. 142 (2), pp. 698-714.

Micco, A. and C. Pages (2006), "The Economic Effects of Employment Protection: Evidence from International Industry-Level Data”, IZA Discussion Paper, No. 2433, Bonn.

Mortensen, D.T. and C.A. Pissarides (1994), "Job Creation and Job Destruction in the Theory of Unemployment", Review of Economic Studies, Vol. 61 (3), pp. 397-415.

Martin, J.P. and S. Scarpetta (2012), "Setting It Right: Employment Protection, Labour Reallocation and Productivity", De Economist, Vol.16 (2), pp. 89-116.

OECD (2010), Employment Outlook, OECD Publishing, Paris.

Pissarides, C. (2010), “Why Do Firms Offer Employment Protection?”, Economica, Vol. 77, pp. 613-636.

Rajan, R. G and L. Zingales (1998), "Financial Dependence and Growth", American Economic Review, Vol. 88 (3), pp. 559-586.

Saint Paul, G. (1996), Dual Labour Markets, MIT Press, Cambridge Massachusetts.

Schivardi, F. and R. Torrini (2008), "Identifying the effects of firing restrictions through size-contingent differences in regulation", Labour Economics, 15 (3), pp. 482-511.

Skedinger, P. (2011), "Employment Consequences of Employment Protection Legislation", Nordic Economic Policy Review, No. 1, pp. 45-83.

Venn, D. (2009), "Legislation, Collective Bargaining and Enforcement: Updating the OECD Employment Protection Indicators", OECD Social, Employment and Migration Working Papers, No. 89.

Venn, D. (2010), "The impact of small-firm exemptions from employment protection", mimeo OECD. 


\section{Annex}

Figure A1. Classification differences arising from different threshold definitions by bandwidth size, 2009

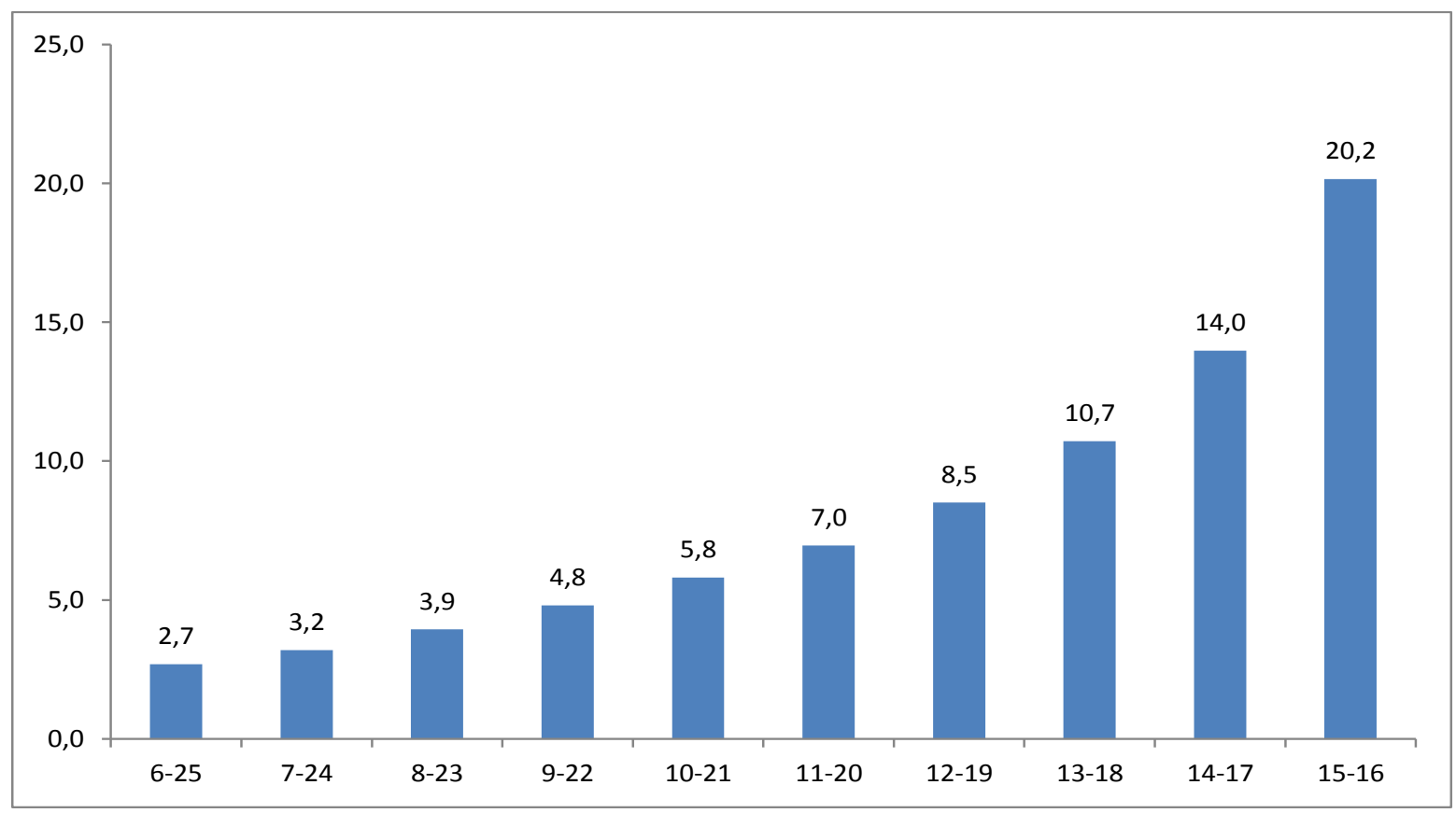


Table A1. Job contracts relevant for the 15 employee threshold

\begin{tabular}{|l|l|l|l|l|}
\hline \multicolumn{1}{|c|}{ Type of contract } & Law & $\begin{array}{c}\text { Leonardi et al } \\
(\mathbf{2 0 1 0})\end{array}$ & $\begin{array}{l}\text { Garibaldi et al (2004) - } \\
\text { Schivardi et al (2008) }\end{array}$ & Hijzen et al (2012) \\
\hline Permanent full time & Yes & Yes & Yes & Yes \\
Temporary full time & Yes & No & Yes & Yes \\
Permanent part time & $\%$ & No & As full time & Part time at $50 \%$ \\
Temporary part time & $\%$ & No & As full time & Part time at $50 \%$ \\
Apprentices & No & No & Yes & Yes \\
Consultants & No & No & No & No \\
\hline
\end{tabular}


Table A2. Conditional labour productivity results

Third-order polynomial in firm size, bandwidth 5-25

\begin{tabular}{|c|c|c|c|c|c|}
\hline & $(1)$ & $(2)$ & (3) & 4) & (5) \\
\hline & \multicolumn{5}{|c|}{ All firms } \\
\hline Treated & $\begin{array}{l}-0.071 \\
{[0.047]}\end{array}$ & $\begin{array}{l}-0.058 \\
{[0.047]}\end{array}$ & $\begin{array}{c}-0.054 \\
{[0.046]}\end{array}$ & $\begin{array}{c}-0.034 \\
{[0.048]}\end{array}$ & $\begin{array}{c}-0.028 \\
{[0.047]}\end{array}$ \\
\hline Incidence of temporary work & & $\begin{array}{c}-0.528^{* * *} \\
{[0.040]}\end{array}$ & & $\begin{array}{c}-0.480^{* * *} \\
{[0.044]}\end{array}$ & \\
\hline Worker reallocation rate & & & $\begin{array}{l}-0.165^{\star \star \star} \\
{[0.009]}\end{array}$ & & $\begin{array}{c}-0.155^{\star \star \star} \\
{[0.010]}\end{array}$ \\
\hline $\begin{array}{l}\text { Treated * } \\
\text { incidence of temporary work }\end{array}$ & & & & $\begin{array}{l}-0.264^{* *} \\
{[0.107]}\end{array}$ & \\
\hline $\begin{array}{l}\text { Treated * } \\
\text { worker reallocation rate }\end{array}$ & & & & & $\begin{array}{l}-0.074^{\star \star *} \\
{[0.024]}\end{array}$ \\
\hline Constant & $\begin{array}{c}11.940^{* * *} \\
{[0.026]}\end{array}$ & $\begin{array}{c}11.978^{\star * \star} \\
{[0.026]}\end{array}$ & $\begin{array}{c}11.984^{* \star *} \\
{[0.026]}\end{array}$ & $\begin{array}{c}11.974^{* \star *} \\
{[0.026]}\end{array}$ & $\begin{array}{c}11.982^{* * *} \\
{[0.026]}\end{array}$ \\
\hline Observations & 34,736 & 34,736 & 34,736 & 34,736 & 34,736 \\
\hline R-squared & 0.013 & 0.018 & 0.026 & 0.019 & 0.027 \\
\hline
\end{tabular}

Standard errors in brackets, ${ }^{* \star *} p<0.01,{ }^{* *} p<0.05,{ }^{*} p<0.1$. 
Table A3. Results by industry, region and age

Third-order polynomial in firm size, bandwidth 5-25

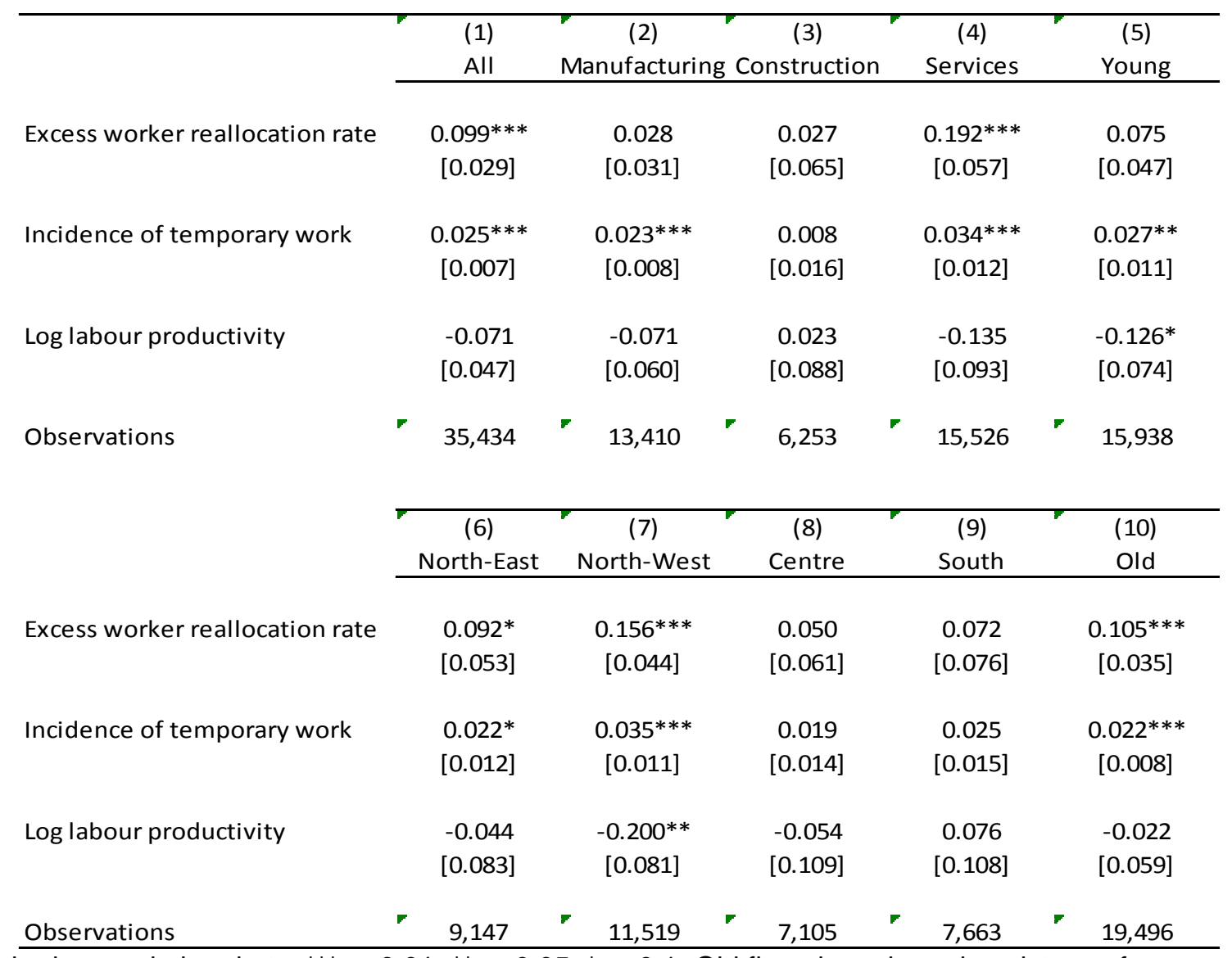

Standard errors in brackets, ${ }^{* * *} p<0.01,{ }^{* *} p<0.05,{ }^{*} p<0.1$. Old firms have been in existence for more than 15 years, while young firms have been in existence for less than 15 years. 
Table A4. Conditional labour productivity results for young firms and firms in the North-West of Italy Third-order polynomial in firm size, bandwidth 5-25

\begin{tabular}{|c|c|c|c|c|c|}
\hline & $(1)$ & $(2)$ & (3) & 4) & (5) \\
\hline & \multicolumn{5}{|c|}{ Young firms } \\
\hline Treated & $\begin{array}{l}-0.126^{\star} \\
{[0.074]}\end{array}$ & $\begin{array}{c}-0.112 \\
{[0.074]}\end{array}$ & $\begin{array}{c}-0.109 \\
{[0.073]}\end{array}$ & $\begin{array}{c}-0.082 \\
{[0.076]}\end{array}$ & $\begin{array}{c}-0.080 \\
{[0.074]}\end{array}$ \\
\hline Incidence of temporary work & & $\begin{array}{l}-0.515^{\star * *} \\
{[0.055]}\end{array}$ & & $\begin{array}{c}-0.469^{\star \star *} \\
{[0.060]}\end{array}$ & \\
\hline Worker reallocation rate & & & $\begin{array}{l}-0.189^{* * *} \\
{[0.011]}\end{array}$ & & $\begin{array}{l}-0.180^{* * *} \\
{[0.011]}\end{array}$ \\
\hline $\begin{array}{l}\text { Treated * } \\
\text { incidence of temporary work }\end{array}$ & & & & $\begin{array}{l}-0.264^{*} \\
{[0.152]}\end{array}$ & \\
\hline $\begin{array}{l}\text { Treated * } \\
\text { worker reallocation rate }\end{array}$ & & & & & $\begin{array}{l}-0.069^{* *} \\
{[0.032]}\end{array}$ \\
\hline Constant & $\begin{array}{c}11.859^{\star \star \star} \\
{[0.042]}\end{array}$ & $\begin{array}{c}11.905^{\star \star \star} \\
{[0.042]}\end{array}$ & $\begin{array}{c}11.923^{* * *} \\
{[0.042]}\end{array}$ & $\begin{array}{c}11.901^{\star \star \star} \\
{[0.042]}\end{array}$ & $\begin{array}{c}11.920^{* * *} \\
{[0.042]}\end{array}$ \\
\hline \multirow[t]{2}{*}{ R-squared } & $\begin{array}{r}15,531 \\
0.006 \\
\end{array}$ & $\begin{array}{c}15,531 \\
0.011 \\
\end{array}$ & $\begin{array}{c}15,531 \\
0.026 \\
\end{array}$ & $\begin{array}{r}15,531 \\
0.012 \\
\end{array}$ & $\begin{array}{c}15,531 \\
0.026 \\
\end{array}$ \\
\hline & \multicolumn{5}{|c|}{ Firms in North-West Italy } \\
\hline Treated & $\begin{array}{l}-0.200^{* *} \\
{[0.081]}\end{array}$ & $\begin{array}{l}-0.174^{\star *} \\
{[0.081]}\end{array}$ & $\begin{array}{l}-0.166^{\star \star} \\
{[0.080]}\end{array}$ & $\begin{array}{c}-0.135 \\
{[0.083]}\end{array}$ & $\begin{array}{l}-0.132 \\
{[0.082]}\end{array}$ \\
\hline Incidence of temporary work & & $\begin{array}{l}-0.728^{* * *} \\
{[0.076]}\end{array}$ & & $\begin{array}{l}-0.660^{\star * *} \\
{[0.084]}\end{array}$ & \\
\hline Worker reallocation rate & & & $\begin{array}{l}-0.202^{* * *} \\
{[0.023]}\end{array}$ & & $\begin{array}{l}-0.190^{* * *} \\
{[0.025]}\end{array}$ \\
\hline $\begin{array}{l}\text { Treated * } \\
\text { incidence of temporary work }\end{array}$ & & & & $\begin{array}{l}-0.411^{* *} \\
{[0.202]}\end{array}$ & \\
\hline $\begin{array}{l}\text { Treated * } \\
\text { worker reallocation rate }\end{array}$ & & & & & $\begin{array}{l}-0.097^{\star} \\
{[0.055]}\end{array}$ \\
\hline Constant & $\begin{array}{l}12.084^{\star * *} \\
{[0.045]}\end{array}$ & $\begin{array}{c}12.131^{* \star *} \\
{[0.045]}\end{array}$ & $\begin{array}{c}12.125^{\star * *} \\
{[0.044]}\end{array}$ & $\begin{array}{c}12.127^{* * *} \\
{[0.045]}\end{array}$ & $\begin{array}{c}12.123^{\star * *} \\
{[0.044]}\end{array}$ \\
\hline Observations & 11,329 & 11,329 & 11,329 & 11,329 & 11,329 \\
\hline R-squared & 0.019 & 0.027 & 0.032 & 0.027 & 0.032 \\
\hline
\end{tabular}

Standard errors in brackets, ${ }^{* *} p<0.01,{ }^{* *} p<0.05,{ }^{*} p<0.1$. Young firms have been in existence for less than 15 years. 
Table A5. CIA tests

Selected coefficients

\begin{tabular}{l|cc|cc|cc}
\hline Bandwidth & \multicolumn{2}{|c|}{$6-25$} & \multicolumn{2}{c|}{$8-23$} & \multicolumn{2}{c}{$10-21$} \\
Treatment status (D) & $\mathrm{D}=0$ & $\mathrm{D}=1$ & $\mathrm{D}=0$ & $\mathrm{D}=1$ & $\mathrm{D}=0$ & $\mathrm{D}=1$ \\
\hline \multirow{3}{*}{ Firm size } & & & & & & \\
& $-0.001^{* * *}$ & -0.000 & -0.000 & -0.000 & 0.000 & -0.001 \\
& {$[0.000]$} & {$[0.001]$} & {$[0.000]$} & {$[0.001]$} & {$[0.001]$} & {$[0.001]$} \\
$\mathrm{N}$ & & & & & & \\
\hline
\end{tabular}

Standard errors in brackets, ${ }^{* * *} p<0.01,{ }^{* *} p<0.05,{ }^{*} p<0.1$. Controls: age, age square and short-time work take-up rate. 